\title{
The S100 Protein Family as Players and Therapeutic Targets in Pulmonary Diseases
}

\author{
Zeeshan Sattar $\mathbb{D}^{1},{ }^{1}$ Alnardo Lora $\mathbb{D}^{1},{ }^{1}$ Bakr Jundi $\mathbb{D}^{1},{ }^{1}$ Christopher Railwah $\mathbb{D}^{1},{ }^{1}$ \\ and Patrick Geraghty (iD) 1,2 \\ ${ }^{1}$ Division of Pulmonary and Critical Care Medicine, Department of Medicine, State University of New York Downstate Health \\ Sciences University, 450 Clarkson Avenue, Brooklyn, NY 11203, USA \\ ${ }^{2}$ Department of Cell Biology, State University of New York Downstate Health Sciences University, 450 Clarkson Avenue, Brooklyn, \\ NY 11203, USA
}

Correspondence should be addressed to Patrick Geraghty; patrick.geraghty@downstate.edu

Received 28 April 2021; Accepted 27 May 2021; Published 19 June 2021

Academic Editor: Kazuyoshi Kuwano

Copyright (C) 2021 Zeeshan Sattar et al. This is an open access article distributed under the Creative Commons Attribution License, which permits unrestricted use, distribution, and reproduction in any medium, provided the original work is properly cited.

\begin{abstract}
The S100 protein family consists of over 20 members in humans that are involved in many intracellular and extracellular processes, including proliferation, differentiation, apoptosis, $\mathrm{Ca}_{2}{ }^{+}$homeostasis, energy metabolism, inflammation, tissue repair, and migration/invasion. Although there are structural similarities between each member, they are not functionally interchangeable. The S100 proteins function both as intracellular $\mathrm{Ca}^{2+}$ sensors and as extracellular factors. Dysregulated responses of multiple members of the S100 family are observed in several diseases, including the lungs (asthma, chronic obstructive pulmonary disease, idiopathic pulmonary fibrosis, cystic fibrosis, pulmonary hypertension, and lung cancer). To this degree, extensive research was undertaken to identify their roles in pulmonary disease pathogenesis and the identification of inhibitors for several S100 family members that have progressed to clinical trials in patients for nonpulmonary conditions. This review outlines the potential role of each S100 protein in pulmonary diseases, details the possible mechanisms observed in diseases, and outlines potential therapeutic strategies for treatment.
\end{abstract}

\section{Introduction to $\mathbf{S 1 0 0}$ Proteins}

In multiple diseases, numerous exogenous and endogenous factors trigger inflammatory cascades. A family of endogenous proinflammatory mediators named damage-associated molecular patterns (DAMPs; also known as alarmins) have become of special interest in the past few decades. During stress reactions or cell injury, DAMPs are released and activate inflammatory pathways [1]. DAMPs function independently when they are intracellular and act in a cytokine-like manner when they are extracellular. Of note, it is suggested that the term "DAMPs" is too broad of a term to characterize all endogenous molecules linked to an inflammatory pathway; thus, there is an ongoing debate on defining DAMPs and classifying them [2]. One family of DAMPs that have been identified to play a significant role in the host immune response in multiple diseases is the S100 protein family.
S100 proteins are involved in both intracellular and extracellular processes including cell apoptosis, migration, protein phosphorylation, calcium balance, differentiation, proliferation, and inflammation [3-6]. The term S100 was first used by Blake Moore to describe proteins that were soluble in 100\% saturated ammonium sulfate in 1965 [7]. There are now 25 such $S 100$ proteins/complexes described, which include 16 S100A proteins (S100A1-S100A16) as well as others (such as S100B, S100G, S100P, and S100Z) [8]. The S100 protein family is exclusively expressed in vertebrates. It consists of small (10-14 kDa), acidic, and calciumbinding proteins (CaBPs) with two distinct EF-hand motifs (helix-loop-helix) [9]. This subfamily of CaBPs exists mainly as homodimers but can also exist as monomers (only S100G is stable in this configuration), heterodimers (S100A1/S100B and S100A8/S100A9), or multimers intra- and extracellularly. Their expression is tissue and cell-type specific [10]. 
Along with $\mathrm{Ca}^{2+}, \mathrm{S} 100$ proteins also bind many other transition metal ions (e.g., $\mathrm{Fe}^{2+}, \mathrm{Cu}^{2+}, \mathrm{Mn}^{2+}, \mathrm{Zn}^{2+}$, and $\mathrm{Ni}^{2+}$ ) that result in a conformational change allowing interaction with target proteins $[11,12]$. S100 proteins act as DAMP molecules and can work as stimulatory ligands for both immune and nonimmune cells, such as endothelial cells [13]. They do so by binding pattern recognition receptors (PRRs) such as toll-like receptor 4 (TLR4) as well as non-PRR DAMP receptors such as advanced glycation end products (RAGE) [14]. By binding to these receptors, S100 proteins trigger downstream nuclear factor $\kappa \mathrm{B}(\mathrm{NF}-\kappa \mathrm{B})$, which results in upregulation of the proinflammatory gene expression $[15$, 16]. In this review, we outline the potential role of the $S 100$ protein members in pulmonary diseases and detail potential molecular mechanisms they may play in disease initiation and progression. Equally, we outline potential therapeutic approaches to treat pulmonary diseases by targeting S100 proteins.

\section{S100 Proteins: Activation, Expression, Interacting Proteins, and Targets}

S100 proteins interact with a variety of target proteins including enzymes, cytoskeletal subunits, receptors, transcription factors, and nucleic acids. Therefore, through structural changes, interactions with $\mathrm{Ca}^{2+}$, posttranslational modifications, receptor-mediated transduction, and direct responses S100 proteins mediate many processes.

2.1. S100 Protein Structure, Calcium Bind, and Posttranslation Modifications. Pending on the cellular and extracellular location of S100 proteins, they can interact with many proteins and form dimers. There are two critical steps for $\mathrm{S} 100$ protein activation: $\mathrm{Ca}^{2+}$ binding [17] and dimer formation [18]. Typically, the $\mathrm{S} 100$ proteins are observed as symmetric dimers, with each S100 subunit containing four $\alpha$-helices [4]. Several heterodimers are reported among family members in vitro, but only the S100A8-S100A9 heterodimer is believed to play a significant role in vivo [19]. S100 subunits contain two $\mathrm{Ca}^{2+}$-binding domains, a carboxyterminal canonical domain composed of 12 amino acids and an amino-terminal domain composed of 14 amino acids [4]. Both are connected by a 10-12 residues region, crucial for target interactions. $\mathrm{Ca}^{2+}$-binding affinity drastically increases when a target engages [20-22]. Upon binding $\mathrm{Ca}^{2+}, \mathrm{S} 100$ proteins undergo conformational rearrangement exposing a hydrophobic cleft that is required for target binding. Therefore, S100 target binding is mostly $\mathrm{Ca}^{2+}$-dependent. Individual S100 family members exhibit differences in surface geometries, hydrophobic residue distribution, and charge density [23]. Several S100 proteins undergo posttranslational modifications, such as oxidative modification, s-nitrosylation, phosphorylation, covalent modification, transglutaminase 2-mediated crosslinking, sumoylation, Sglutathionylation, cysteinylation, the formation of intraand intersulfinamide bonds, or intracellular localization [24-29]. The activity of S100 proteins is regulated by metal ions, such as calcium, zinc, and copper, that modulate the folding and oligomerization of the protein [30]. Regarding pulmonary disease, few studies focus on the structure or modification of S100 proteins but merely their presence or the impact of deficiency or inhibition on disease initiation or progression.

2.2. S100 Expression Profile. Each S100 family protein is encoded by a separate gene, mostly but not limited to chromosome 1q21 [9]. When examining the expression of each S100 gene between different cell types or tissues, despite structural similarities and clustered genes, each S100 gene has a very specific expression pattern [31-33]. Therefore, we must not expect similar expression patterns for each S100 gene member. Dysregulated expression of multiple S100 family members occurs in most diseases. Epigenetic events are reported in various medulloblastoma cell lines resulting in dysregulated S100 gene expression [34]. DNA de-methylation and hypomethylation [35] and micro-RNA regulation are reported in the regulation of the $\mathrm{S} 100$ gene expression. $\mathrm{CpG}$ islands are observed in the $5^{\prime}$ regulatory regions of S100A2, S100A6, S100A10, and S100A11 genes, within the proximal promoter and the first two introns [36]. Methylation of these islands is typically associated with a repressed chromatin state and transcription inhibition. But not all S100 genes contain these CpG islands, such as S100P and S100Z genes. Equally, several S100 genes are reported to be upregulated due to several extracellular factors, such as oxidative stress, certain cytokines, and growth factors in many types of cells [37]. Within pulmonary diseases, the expression of $\mathrm{S} 100$ genes is reported to be primarily triggered by extracellular responses. Importantly, different subsets of monocytes can have different expression profiles of S100 proteins [38]. Our group demonstrated that the protein tyrosine phosphatase (PTP1B) could negatively regulate the S100A9 expression and reduced S100A9 stimuli responses via regulation of TLR4 signaling [39]. However, there are several other means to regulate the S100A9 expression as it is sensitive to the Src kinase inhibitor PP2 [40] and the STAT3 expression [41]. Therefore, the S100 gene expression varies depending on the cell type, tissue, external stimuli, age, and possible sex.

2.3. Secretion of $\$ 100$ Proteins. Little is known about the mechanisms that mediate the secretion of S100 proteins. The S100 proteins lack a leader sequence and are not secreted via the classical Golgi pathway. The secretion of S100 proteins appears to occur either passively upon cell necrosis or actively following cell activation. Several S100 proteins undergo secretion following stimulation by particular cell activators, such as serotonin-receptor agonists [42], antidepressants, glutamate, adenosine, IL- $1 \beta$ [43], lysophosphatidic acid, and changes in extracellular $\mathrm{Ca}^{2+}$ and $\mathrm{K}^{+}$levels [44]. Some S100 proteins have affinities to lipid structures that may allow them to translocation across the plasma membrane following cell stress or activation [45]. Equally, S100 proteins can interact with phospholipid-binding proteins, such as S100A10 binding to Annexin A2 [46], to induce exocytosis of intracellular S100 proteins to the extracellular domain. S100 protein members, S100A8/S100A9, may be released from necrotic myeloid cells or actively secreted following translocation to the membrane, utilizing an intact 
microtubule network and PKC activation [47]. Oxidative stress can induce the release of $\mathrm{S} 100$ proteins from several cells. S100A8/S100A9 could be released neutrophil extracellular traps (NETs). Therefore, S100 proteins may be readily secreted within the lungs. Expression levels and plasma or BALF levels of several S100 proteins are observed to be altered in the lungs of several pulmonary diseases, as outlined in Section 3 and Table 1.

2.4. S100 Protein Receptors and Targets. Once released to the extracellular space, S100 proteins trigger immune cell activation through binding to different cell surface receptors. S100 proteins primarily trigger inflammation responses through their interactions with toll-like receptor (TLR) 4 and receptor for advanced glycation end products (RAGE) [48]. S100A8 and A9 are known to bind to TLR4 [48], while S100A7, S100A12, S100A8/A9, and S100B interact with RAGE [16, $49,50]$. By interacting with RAGE and/or TLR4, S100 proteins can activate mitogen-activated protein kinases (MAPK) responses and transcription factors, such as NF- $\kappa \mathrm{B}$, resulting in the production of proinflammatory cytokines [50, 51]. S100A6 activates RAGE to promote apoptosis [52]. However, S100B inactivates RAGE [53]. S100 proteins are also known to interact with extracellular matrix metalloproteinase inducer (EMMPRIN) (also known as CD147), G-proteincoupled receptor (GPCR), CD36 [54], FGFR1 [55], CD166 antigen [56], IL-10 receptor [57], neuroplastin- $\beta$ [58], CD68 [59], and ErbB4 [60] (see Figure 1). It is important to note that S100 protein heterodimers and the presence of calcium may also influence different receptor responses.

\section{Linking S100 Proteins to Pulmonary Disease Outcomes}

Multiple sources suggest that S100 protein family members augment the inflammatory response and disease outcomes in a variety of different pulmonary diseases.

3.1. S100A1. S100A1 is a small $(\sim 10 \mathrm{kDa})$ protein that predominantly functions to modulate the $\mathrm{Ca}^{2+}$ milieu, energy metabolism, and contraction of the cardiac myocytes [61]. It is also shown to be present in vascular endothelial cells and smooth muscle cells, and its absence is associated with a hypertensive phenotype in animal models partly secondary to endothelial cell dysfunction $[62,63]$. Teichert-Kuliszewska et al. demonstrated that S100A1 is also expressed in the lung vascular endothelium, and its deficiency in knockout (KO) mice leads to increased right ventricular (RV) systolic pressure (RVSP) as well as aberrant endothelial-dependent relaxation in response to acetylcholine and decreased availability of nitric oxide (NO) thus predisposing to pulmonary hypertension [61]. Pigs embolized with Sephadex developed RV hypertrophy and, interestingly, showed increased RV S100A1 expression and mild pulmonary hypertension $(\mathrm{pH})$ [64].

3.2. S100A2. S100A2 is linked to both suppressions of tumor progression as well as being a promoter of carcinogenesis [65-69]. Its role in non-small-cell lung cancer (NSCLC) was elucidated by Feng et al. who suggested that hypermethy- lation of the promoter region of the S100A2 gene led to its downregulation in the early stages of NSCLC carcinogenesis thus contributing to tumor progression [68]. In contrast, some data suggest that overexpression of S100A2 may indicate a poor prognosis in stage 1 NSCLC [70]. EGFstimulated EGFR phosphorylation induces the S100A2 expression, and S100A2 exhibits antitumor activity by reducing the rate of tumor growth when overexpressed in nude mice with NCI-H2172 cell tumor xenograft model [71].

3.3. S100A3/S100A13. Mutation of the S100A3 gene leads to the replacement of arginine with cysteine at the 77 th position of the S100A3 protein along with a mutation of the S100A13 gene leading to decreased expression of both proteins. This is implicated in an atypical genetic variant of early onset interstitial pulmonary fibrosis [72]. The decreased expression of these proteins leads to abnormal calcium homeostasis intracellularly, decreased tolerability of oxidative stress, and altered expression of extracellular matrix proteins. In addition to its role in idiopathic pulmonary fibrosis (IPF), S100A3 is also a potential drug target in lung cancers. Gianni et al. showed that knockdown of S100A3 leads to degradation of $\operatorname{RAR} \alpha$, a transcription factor that plays a role in the antiproliferative effects of All-trans retinoic acid (ATRA) [73], by proteasomes thus inducing resistance to the antiproliferative and differentiating effects of ATRA on lung cancer cells [74]. Tumor microvascular density (MVD) is an indicator of tumor neovascularization which advocates recurrence, potential for metastases, and survival of cancerous cells. Overexpression of S100A13 in stage I NSCLC has been associated with enhanced intratumoral MVD. This suggests that S100A13 plays a role in lung cancer progression and metastasis [75]. Similarly, it is associated with a more aggressive invasive phenotype of lung cancer [76].

3.4. S100A4. S100A4 was originally labeled as a specific marker of fibroblasts in different tissues and was termed as FSP-1 (fibroblast-specific-protein-1), but further studies showed that S100A4 is also involved in the fibrogenic of mesenchymal progenitor cells in the lung thus contributing to the pathogenesis of IPF [77]. S100A4 is released by M2 alveolar macrophages, which then activates fibroblasts [77]. Inhibition of the S100A4 expression with niclosamide improved survival in a bleomycin-induced fibrosis model in mice [77]. Bleomycin significantly increases the S100A4 expression in alveolar macrophages [77]. Extracellular S100A4 activates lung fibroblasts by the upregulation of $\alpha$-SMA, type I collagen, and sphingosine-1-phosphate (S1P) [78]. S100A4 is also involved in the pathogenesis of lung cancer through inhibition of autophagy [79], a process by which defective proteins and organelles are degraded in lysosomes to maintain the cellular milieu [80, 81]. S100A4 inhibits starvationinduced autophagy, thus promoting the proliferation of NSCLC cells through activation of the Wnt/ $\beta$-catenin pathway in a RAGE-dependent manner [79]. S100A4 regulates oxygen consumption rates, mitochondrial activity, ATP production, and glycolytic activity by regulating mitochondrial complex I subunit NADH dehydrogenase (ubiquinone) $\mathrm{Fe}$ $S$ protein 2 (NDUFS2) [82]. Interestingly, S100A4 has some 
TABLE 1: S100 proteins involved in pulmonary diseases.

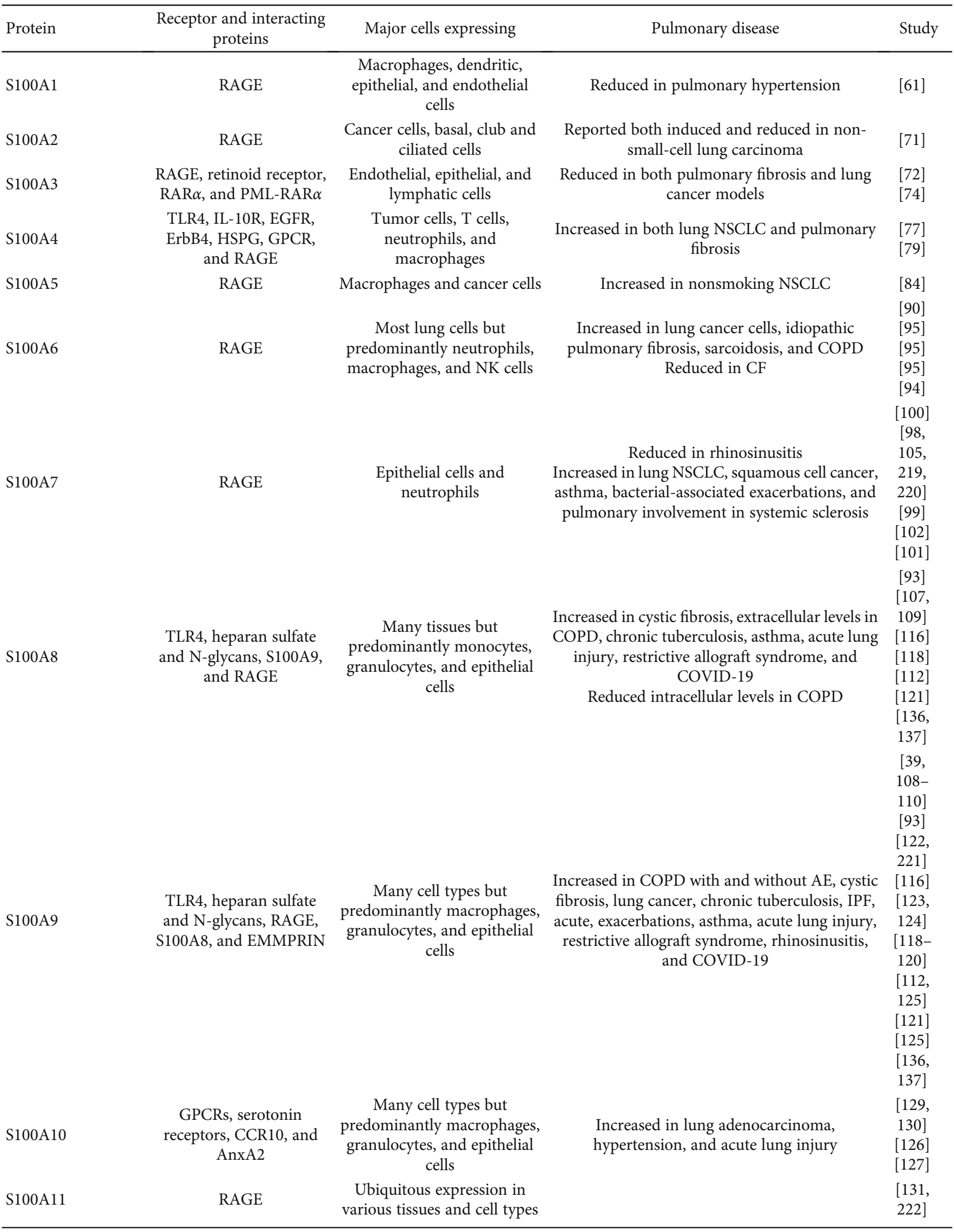




\begin{tabular}{|c|c|c|c|c|}
\hline & & & $\begin{array}{l}\text { Increased in lung adenocarcinoma, } \\
\text { hypertension, idiopathic pulmonary fibrosis, } \\
\text { sarcoidosis, and COPD }\end{array}$ & $\begin{array}{l}{[223]} \\
{[95]} \\
{[95]} \\
{[95]}\end{array}$ \\
\hline S100A12 & $\begin{array}{c}\text { TLR4, RAGE, N-glycans, } \\
\text { scavenger receptors, and } \\
\text { GPCR }\end{array}$ & Granulocytes and monocytes & $\begin{array}{l}\text { Increased in asthma, COPD, ARDS, restrictive } \\
\text { allograft syndrome, and COVID-19 }\end{array}$ & $\begin{array}{l}{[134,} \\
135] \\
{[109]} \\
{[224]} \\
{[121]} \\
{[136,} \\
137]\end{array}$ \\
\hline S100A13 & RAGE & $\begin{array}{l}\text { Ubiquitous expression in } \\
\text { various tissues and cell types }\end{array}$ & $\begin{array}{l}\text { Increased in pulmonary fibrosis and lung cancer } \\
\text { cells }\end{array}$ & $\begin{array}{l}{[72]} \\
{[75} \\
225]\end{array}$ \\
\hline S100A14/S100A11P & RAGE & $\begin{array}{l}\text { Epithelial cells and cancer } \\
\text { cells }\end{array}$ & Increased in lung adenocarcinoma and NSCLC & $\begin{array}{l}{[139} \\
226 \\
227]\end{array}$ \\
\hline S100A15 & GPCR & Cancer cells and neutrophils & Increased in lung adenocarcinoma & [140] \\
\hline S100A16 & $\begin{array}{l}\text { Unknown receptor } \\
\text { interaction but binds to } \\
\text { S100A14 }\end{array}$ & $\begin{array}{l}\text { Cancer, epithelial, endothelial } \\
\text { cells, and fibroblasts }\end{array}$ & Increased in lung adenocarcinoma and NSCLC & $\begin{array}{l}{[141,} \\
142]\end{array}$ \\
\hline S100B & RAGE and FGFR1 & $\begin{array}{l}\text { Cancer cells, dendritic cells, } \\
\text { and lymphocytes }\end{array}$ & Increased in lung SCL but reduced in NSCLC & $\begin{array}{c}{[145]} \\
{[84]}\end{array}$ \\
\hline S100G & Annexin A10 & Epithelial and cancer cells & Increased in lung NSCLC & {$[84]$} \\
\hline S100P & RAGE and p53 & Epithelial and cancer cells & $\begin{array}{c}\text { Increased in restrictive allograft syndrome, lung } \\
\text { NSCLS, adenocarcinoma, and pulmonary } \\
\text { arterial hypertension }\end{array}$ & $\begin{array}{c}{[121]} \\
{[146} \\
148, \\
149] \\
{[150]}\end{array}$ \\
\hline S100Z & $\begin{array}{c}\text { S100A1, S100A3, and } \\
\text { S100B }\end{array}$ & Monocytes and dendritic cells & No known pulmonary link & \\
\hline
\end{tabular}

antitumorigenesis properties as $10 \%$ of $S 100 a 4^{-/-}$mice develop spontaneous tumors that are p54 positive, including bronchioalveolar carcinomas [83]. This loss of S100a4 in mice coincided with elevated $\$ 100 a 3$ and $\$ 100 a 5$ expression in several tissues [83].

3.5. S100A5/S100G. The prognostic value of high levels of expression of S100A5 and S100G mRNA is associated with worse overall survival in the nonsmoking NSCLC patients [84]. Further studies are warranted to further elucidate the role of S100A5 as a prognostic marker in lung cancer. However, differential expression of S100A5 is observed in primary human bronchial epithelial ( $\mathrm{HBE}$ ) isolated from healthy, asthmatic, and COPD donors grown at the air-liquid interface when exposed to fine particulate matter [85].

3.6. S100A6. S100A6 plays a role in the proliferation, apoptosis, cytoskeleton modulation, and stress-induced responses of normal adult cell types as well as several tumorous cells [86]. It is overexpressed in lung cancer cells and serum from cancer patients $[87,88]$. S100A6 plays a role in the proliferation, invasion, migration, and angiogenesis of lung cancer cells by degrading p53 acetylation, a process by which p53 gets activated and performs its role as a tumor suppressor [89]. The S100A6 expression is downregulated by overexpression of the microRNA, miRNA-193a, thereby increasing p53 acetylation [90]. Hematopoietic stem cells from S100a6 $6^{-1-}$ mice have impaired self-renewal and regenerative capacity [91]. Chronic exposure to cigarette smoke increases S100A6 lung levels in Wistar rats [92]. Mice deficient for the cystic fibrosis (CF) transmembrane conductance regulator (CFTR) gene develop multiple complications, including severe pulmonary disease. Male $\mathrm{Cft}^{-/-}$mice have elevated lung S100a8 and S100a9, while demonstrating reduced S100a6 and S100a13 [93]. A recent study suggests that there is an S100A6 profile in systemic sclerosis and may represent a potential biomarker [94]. Finally, although the levels of S100A6 along with S100A11 are different between IPF, sarcoidosis, and COPD subjects and healthy controls, there was no prognostically significant [95].

3.7. S100A7. The majority of early work looking at S100A7, also called psoriasin, focused on psoriasis $[96,97]$. However, several studies suggest that S100A7 may have a role in several respiratory diseases, including lung cancer [98], asthma [99], rhinosinusitis [100], pulmonary complications of systemic sclerosis [101], and bacterial exacerbations [102]. S100A7 is a chemotactic protein for CD4+ T cells and neutrophils present in the skin epidermis [103]. It also functions as a direct bactericidal protein [104]. Kim et al. demonstrated that levels of S100A7 and S100A8/A9 were reduced in chronic rhinosinusitis (CRS) patients with a mixed ball of bacteria and fungi compared to a fungal ball [100]. This implies that the barrier function of the nasal epithelial cells is reduced in mixed 


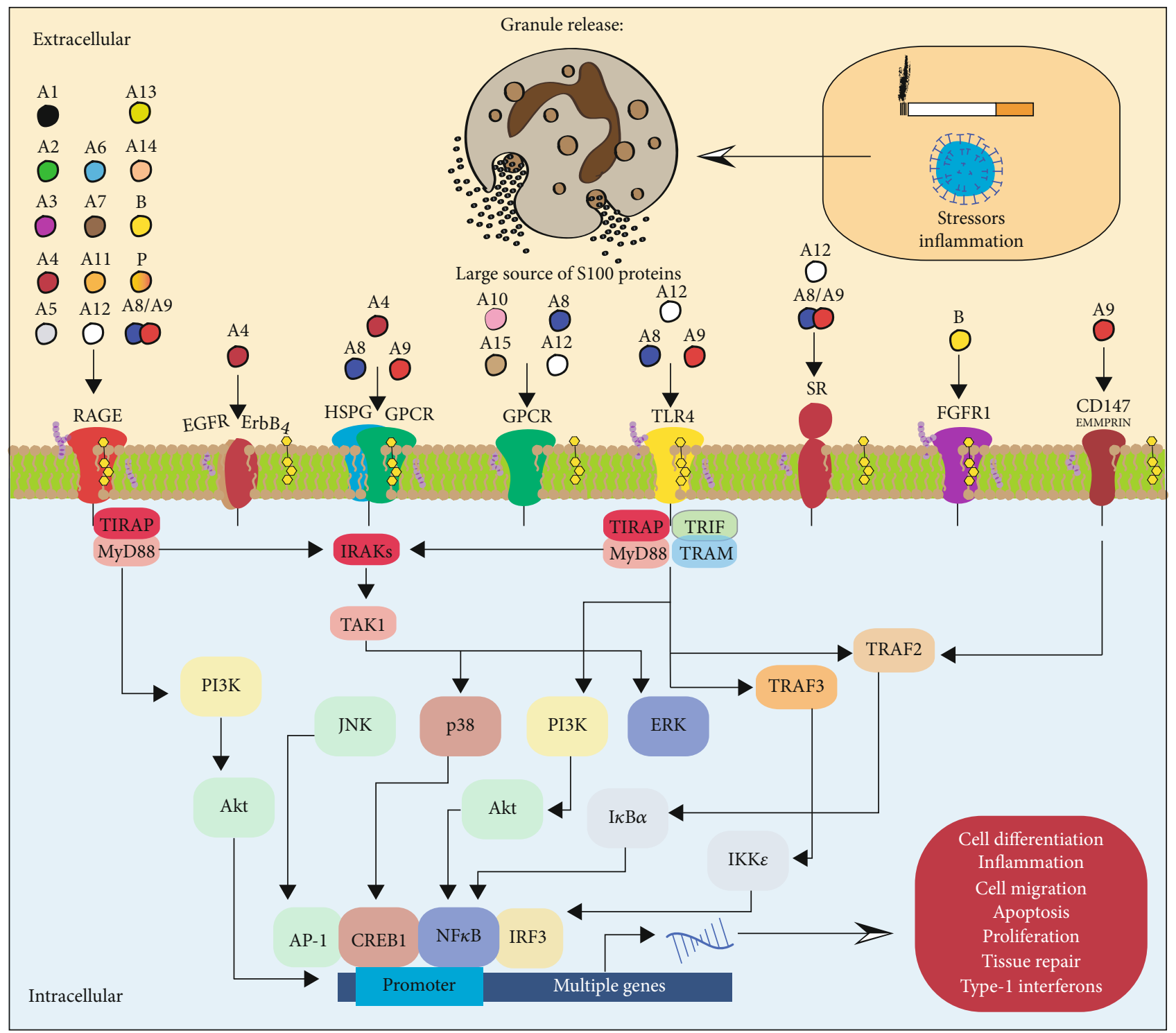

FIGURE 1: Extracellular functions of S100 proteins. Several factors can trigger S100 proteins to be released or secreted from multiple cell types, including granulocytes. The extracellular S100 proteins interact with several pattern recognition receptors, resulting in proinflammatory signaling pathways that promote cell differentiation, inflammation, migration, apoptosis, proliferation, tissue repair, and a robust type-1 interferon response. Only a portion of the RAGE, HSPG/GPCR, TLR4, and CD147 responses are shown here. RAGE: receptor for advanced glycosylation end products; EGFR: epidermal growth factor receptor; ErbB: v-erb-b2 avian erythroblastic leukemia viral oncogene homolog; HSPG: heparan sulfate proteoglycans; GPCR: G $\alpha$ 9-coupled receptor; TLR4: toll-like receptor 4; SR: scavenger receptor; FGFR1: fibroblast growth factor receptor 1; CD147: cluster of differentiation 147; EMMPRIN: extracellular matrix metalloproteinase inducer; TIRAP: TIR domain containing adaptor protein; MyD88: myeloid differentiation factor 88; IRAK: interleukin 1 receptor-associated kinase; TAK1: transforming growth factor- $\beta$ - (TGF $\beta$-) activated kinase 1; TRIF: TIR-domain-containing adaptor protein inducing IFN $\beta$; TRAM: translocating chain-associated membrane; TRAF: TNF receptor-associated factor; PI3K: phosphoinositide 3-kinases; Akt: protein kinase B; JNK: JUN N-terminal kinase; ERK: extracellular signal-regulated kinase; AP-1: activator protein 1; CREB1: cAMP-responsive element-binding protein 1 ; NF- $\kappa \mathrm{B}$ : nuclear factor- $\kappa \mathrm{B}$; IRF: interferon regulatory factor; I $\kappa \mathrm{B} \alpha$ : nuclear factor of kappa light polypeptide gene enhancer in B cell inhibitor, alpha; IKK: inhibitor of NF- $\kappa$ B kinase.

fungal and bacterial infections thus putting patients at risk of developing an invasive fungal infection.

S100A7 also appears to play a role in the pathogenesis of NSCLC. A study investigating the TGF $\beta$ signaling pathway in the progression of NSCLC demonstrated that the TGF $\beta$ induced long noncoding RNA (TBILA) binds to S100A7 thus activating the S100A7/JAB1 pathway leading to NSCLC pro- liferation and metastasis [98]. The S100A7 expression is induced by activation of the Hippo pathway and acts as a facilitator in the adenosquamous transition of lung cancer cells [105]. S100A7 levels are higher in lung squamous carcinoma and have the potential to be used as a diagnostic marker as its levels are elevated in cancerous cells as compared to nonneoplastic cells [106]. Knockdown of S100A7 
leads to decreased phosphorylation of NF- $\mathrm{KB}$ thus inhibiting tumor proliferation. This marks S100A7 as a potential therapeutic target for the treatment of lung squamous cell cancers [106].

In asthma, S100A7 plays a role in the interplay between the proinflammatory cytokine IFN- $\gamma$ and IL-22. The expression of S100A7 is induced by IL-22, and these effects are in turn inhibited by IFN- $\gamma$ [99]. The expression of S100A7 is enhanced in cases where $S$. aureus is found in the respiratory tract thus stressing the role of this molecule in the epithelial barrier of the lower respiratory tract [102]. S100A7 levels correlate with lung involvement in systemic sclerosis, and the increased expression of psoriasin in the whole saliva has a specificity of $50 \%$ and a sensitivity of $85 \%$ in detecting lung involvement in this condition [101].

3.8. S100A8 and S100A9. As mentioned above, S100A8 and S100A9 proteins are upregulated in $\mathrm{Cftr}^{-/-}$animals, thus suggesting a role of these proteins in the disease process of $\mathrm{CF}$ [93]. The anti-inflammatory role of S100A8 in emphysema was investigated by Lin et al., and low intracellular S100A8 levels were observed in emphysema that correlated with disease severity. Furthermore, this protein also has a cytoprotective role, as it is shown that the knockout of this protein leads to oxidative stress-induced cell apoptosis while elevated levels prevent cellular injury [107]. Interestingly, the S100A8/A9 heterodimer may play a role in acute exacerbations of COPD, as it is negatively associated with FEV1\% in these patients [108]. Similarly, another study observed elevated S100A8 and S100A9 in COPD samples [109]. Our group has identified S100A9 signaling in smoke and agerelated COPD progression [110]. Levels of S100A9 are elevated in older animals as well as animals exposed to cigarette smoke [110]. The unique intracellular and extracellular responses of both of these proteins require further investigation in the lungs. Similar to COPD, it appears that S100A8, S100A9, and the S100A8/A9 heterodimer have opposite effects in acute lung injury (ALI). S100A8 similarly inhibits ALI to dexamethasone [111] while S100A9 and calprotectin (the S100A8/A9 complex) promote neutrophil influx by increasing mast cell degranulation and upregulation of particular chemokines. S100A8 is IL-10 dependent while S100A9 and calprotectin do not induce IL-10 in the airways or tracheal epithelial cells [112].

The S100A8/A9 complex is expressed in tuberculosis (TB) [113-115], as S100A8/A9-expressing neutrophils are observed to assemble in granulomas and S100A8/A9 levels correlated with active disease [113]. This protein also mediates neutrophil accumulation in chronic TB by upregulating the integrin molecule CD11b [116]. The levels of both of these proteins in BALF and sera of asthmatic patients correlate with elevated levels of serum IgE [117]. In addition, they inhibit the apoptosis of neutrophils by increasing the levels of MCP-1, IL-6, and IL-8 through the PI3K/AKT/MAPK/NF$\kappa \mathrm{B}$ pathway [118]. S100A9 enhances the migration of fibrocytes in asthma exacerbations as well as chronic obstructive asthma [119]. S100A9 and/or S100A8/A9 may also have an anti-inflammatory function in asthma by downregulating the function of $\mathrm{CD}^{+}$Treg cells [120].
Saito et al. elucidated the role of alarmins in chronic lung allograft dysfunction (CLAD), a major contributor to morbidity and mortality in long-term survivors of lung transplantation [121]. The two subtypes of CLAD, restrictive allograft syndrome (RAS) and bronchiolitis obliterans syndrome (BOS), exhibited distinct expression patterns of alarmins including S100A8, S100A9, S100A8/A9, S100A12, S100P, HMGB1 (high mobility group box-1), and soluble RAGE suggesting different biologic profiles of CLAD subtypes. S100A8/A9 overexpression could be involved in the interaction of metastatic lung cancer cells and bone marrow adipocytes leading to bone destruction [122]. S100A8 and S100A9 are upregulated in the acute exacerbations of idiopathic pulmonary fibrosis (IPF) suggesting roles of different signaling pathways like Clathrin-mediated endocytosis signaling, atherosclerosis signaling, and IL2 signaling in the pathogenesis of acute exacerbations of IPF [123]. Serum S100A8/A9 levels are significantly increased in patients with IPF compared with healthy controls and correlate with the diffusing capacity for carbon monoxide (DLCO) and the composite physiologic index [124]. Finally, elevated levels of S100A9 protein are present in the nasal tissues of chronic rhinosinusitis (CRS) subjects. S100A9 mediates the MMP3 expression, resulting in nasal epithelial cell proliferation [125].

3.9. S100A10. S100A10 is believed to be a signature gene involved in blood pressure regulation and maybe a potential target for the detection of risk, prevention, and treatment of hypertension [126]. S100A10 is also one of the cytoskeletal regulatory proteins. It enhances endothelial cell barrier function and is recruited to the caveolin-induced microdomains by high-molecular-weight hyaluronan [127] and potentially could contribute to syndromes of endothelial dysfunction like acute lung injury and sepsis. In primary lung cancers, S100A10 overexpression is associated with higher stage and invasiveness of lung adenocarcinoma [128] as well as lymphatic invasion, cancer stage progression, and poor prognosis in lung squamous cell carcinoma [129]. Increased expression of Kallikrein-related peptidase 6, a serine protease that is normally expressed in mammary tissue, is linked with the enhanced metastatic potential of breast cancer to the lungs and elevated expressions of S100 proteins, like S100A4 and S100A11 [130]. On the contrary, expression at physiological levels leads to suppression of some S100 proteins (S100A4, S100A10, S100A13, S100A16) and thus inhibition of lung metastases.

3.10. S100A11. S100A11 also called S100C or calgizzarin, overexpression is linked with alterations in K-RAS mutated lung adenocarcinomas as well as poorly differentiated lung adenocarcinomas [131]. It is associated with shorter disease-free survival in these tumors. S100A11 levels are increased in the plasma of patients with pulmonary arterial hypertension (PAH) [132]. Hypoxia-induced mitogenic factor, a protein upregulated in animal models of PAH and asthma, is associated with S100A11mediated smooth muscle cell migration, vesicular exocytosis, and nuclear activation [133]. 
3.11. S100A12. S100A12 is strongly expressed in the early stages of ALI and early acute respiratory distress syndrome (ARDS) [134]. Possible effects of overexpression include activation of pulmonary endothelium, leukocyte extravasation, and neutrophil accumulation leading to lung injury. Thus, this protein has the potential to be used as a marker of inflammation in ARDS. Contrary to ARDS and ALI, one study demonstrated that this protein blunts inflammatory responses in asthma in murine models [135]. It is also reported to be elevated in COVID-19 patients [136, 137].

3.12. S100A14. The S100A14 expression is associated with a subset of lung adenocarcinoma and has a strong correlation with the invasive and migratory nature of lung adenocarcinoma cells [138]. Its expression is also increased in NSCLC where it has been demonstrated to act as a target of miR$335-3 p$ contributing to NSCLC progression through the pathway involving cancer susceptibility candidate-9, a long noncoding RNA (lncRNA) [139].

3.13. S100A15 and S100A16. Both S100A15 (S100A7A gene) and A16 expression are altered in lung cancers. Increased S100A15 expression and decreased DNA methylation of its gene promoter region are associated with poor outcomes in lung adenocarcinoma cases and potentially greater metastasis [140]. The S100A16 expression is increased in NSCLC [141] as well as adenocarcinoma [142] and is a potential marker for prognosis in patients with these varieties of lung cancer.

3.14. S100B. S100B is a nervous system-specific protein and is expressed in glial and Schwann cells [143]. Its levels can rise in response to increased blood-brain barrier permeability $[143,144]$. Increased expression of this protein is associated with brain metastases in patients with small cell lung cancer (SCLC) and may indicate poor prognosis as higher levels are linked with shorter survival time [145]. In contrast, increased S100B mRNA expression is associated with better survival in smoking NSCLC patients [84].

3.15. S100P. The S100P expression is associated with the migration, invasiveness, and metastasis of lung cancer [146] as well as the migration of NSCLC [147]. S100P, as an immune-associated gene (IAG) signature, can potentially be used in risk score models to predict the overall survival, stage, lymph node accumulation, tumor metastasis, B cells, and dendritic cell infiltration of lung adenocarcinoma [148]. S100P is sequestered by NORAD, an IncRNA, thereby playing a role in the inhibition of metastatic potential of lung and breast cancers [146]. The transcriptional activation of S100P can be regulated by Porcupine proteins thus contributing to the development of NSCLC [149]. S100P may also play a role in the pathogenesis of pulmonary hypertension in patients with systemic sclerosis as it is overexpressed in these patients [150].

\section{Role and Mechanisms of S100 Proteins in Pulmonary Diseases}

4.1. S100 Protein-Mediated Signaling in Pulmonary Diseases. In noncancerous pulmonary diseases, several S100 proteins
(S100A1, A4, A8, A9, A12, and B) are noted to induce multiple pathways associated with pulmonary disease phenotypes. Here, we will outline the known signaling transduction of these S100 proteins in noncancerous pulmonary diseases. The primary pathways investigated are TLR4 and RAGEmediated (Figure 1 and Table 1).

Deficiency of S100a1 results in pulmonary hypertension in mice due to enhanced eNOS activity and nitric oxide levels, via Akt/ERK1/2 pathways, and reduced endothelial cell survival [61]. Alternatively, overexpressing S100A4 in mice results in the development of RAGE-mediated pulmonary arterial hypertension in females [151]. Stimulation with $17 \beta$-estradiol increases the S100A4 expression and proliferation in human pulmonary artery smooth muscle cells, and this proliferation is prevented by blocking RAGE signaling [151]. S100A4 also prevents autophagy and induces proliferation in A549 and Lewis lung carcinoma cells, via the RAGE and Wnt pathways [79].

Similarly, S100A9 promotes proliferation of lung fibroblasts and upregulated expression of proinflammatory cytokines (IL-6, IL-8, IL-1 $\beta$ ) and collagen type III, via ERK and NF- $\kappa$ B signaling [152]. The S100A8/S100A9 dimer induces the secretion of cytokines, such as MCP-1, IL-6, and IL-8, from bronchial epithelial cells in a TLR4/Akt mediated pathway [118]. This process prevented neutrophil apoptosis in cell coculture experiments [118]. Cigarette smoke is known to modulate the signaling of TLR4 [153], RAGE [154], and EMMPRIN [155]. Our group determined that enhanced S100A9 signaling coincides with lung damage during respiratory syncytial virus (RSV) infection in mice [39]. We determined that S100A9 is enhanced by cigarette smoke exposure and further enhanced during viral exacerbations in mice and human primary lung cells [39]. We also recently demonstrated that cigarette smoke-induced S100A9 contributes to loss of lung function, airspace enlargements, elastin degradation, enhanced phosphorylation of ERK and c-RAF, and altered expression of MMP-3, MMP-9, MCP-1, IL-6, and KC/IL-8 [110]. Equally, elevated S100A9 levels in the lungs correlate with aging [110]. This is also reported in the central nervous system [156] and may occur with other S100 proteins within the lung as S100B blood levels are agerelated [157, 158]. Interestingly, p-PKA $\alpha$ interacts with S100A8 in lung tissue obtained from smokers [107]. This interaction alters the phosphorylation of serine within S100A8 and subsequent S100A8 protein destabilization and degradation [107]. Loss of S100A8 increases the percentage of apoptotic A549 cancer cells [107]. S100A8/S100A9 also acts as a chemotactic factor by inducing neutrophil adhesion [159] and can induce ROS-mediated apoptosis, autophagy, mitochondrial damage, and lysosomal activation in various cell types, including lymphocytes, macrophages, endothelial cells, and tumor cells [51]. Expressions of S100a8 and S100a9 are both elevated in the lungs of CF transmembrane conductance regulator (Cftr) knockout mice, while S100a6 and S100a13 are reduced [93]. S100A8/A9 also regulates CD11b expression and neutrophil recruitment during chronic tuberculosis [116]. Interestingly, the downregulation of S100A8 and S100A9 is associated with the differentiation of myeloid cells toward dendritic cells and macrophages 
[160]. Alternatively, $\mathrm{S}_{100 \mathrm{~A} 9^{-/-}}$mice displayed significantly enhanced allergic airway inflammation upon exposure to Alternaria alternata, including IL-13, CCL11, CCL24, serum IgE, lung eosinophils, IL- $13^{+} \mathrm{IL}-5^{+} \mathrm{CD} 4^{+} \mathrm{T}$-helper type 2 cells, airway resistance, and elastance [120]. Recently, we observed that S100A9 expression in chronic rhinosinusitis samples coincides with elevated plasma proteases, and S100A9 protein enhances MMP-7 and MMP-3 production and proliferation in the CCL-30 cell line [125].

Finally, S100A12 and S100B signaling is observed in the lungs. Mice expressing the human S100A12 gene have reduced peribronchial and perivascular inflammation, mucus production, eosinophilia, and airway responsiveness [135]. This was associated with S100A12 induced Fas expression and activation of caspase 3 in cultured airway smooth muscle cells, thereby leading to reduced airway smooth muscle [135]. In bronchial epithelial cells, the S100B expression is upregulated due to MyD88-dependent activation of canonical NF- $\kappa \mathrm{B}$ in the early stages of fungal infection but later becomes downregulated via TLR-3/9-dependent signaling [161]. CD8+ T cells and NK cells also express and secrete S100B following stimulation [162].

4.2. S100 Proteins in Tissue Repair. Despite S100 proteins being associated with cellular and tissue damage, several members (including S100A7, S100A8/A9, S100A12, and S100A15) are reported to also play a critical role in tissue repair [163]. These S100 proteins are reported to be involved in tissue repair in atherosclerosis, dermatitis, and arthritis [14]. Importantly, S100A4 promotes muscle tissue repair to maintain contractility following heart injury [164]. Within pulmonary diseases, little is reported on the role of $\mathrm{S} 100$ proteins in tissue repair. However, intracellular S100A8 was recently shown to protect type II pneumonocytes from smoke-induced cell death [107]. Hiroshima and colleagues demonstrate that S100A9 and S100A8/A9 can reduce neutrophil influx in the LPS model of acute lung injury [112]. Since S100A8/A9 and LPS target TLR4, S100A8/A9 may compete for TLR4 binding with LPS. Interestingly, $S 100 a 9^{-1-}$ mice accumulated a lower frequency of CD4+ T regulatory (Treg) cells following exposure to Alternaria alternata [120], leading to more lung damage. Equally, despite S100B responses activating intracellular TLRs, during a pulmonary Aspergillus fumigatus infection, S100B can itself resolve inflammation via transcriptional inhibition of itself [161]. Therefore, several members of the S100 family could influence cell fate, inflammation, and tissue remodeling within the lungs. There may also be several feedback loops that initially trigger inflammation and subsequently regulates the resolution of these responses to minimize damage and facilitate repair.

\section{Targeting S100 Proteins to Treat Pulmonary Diseases}

Due to the involvement of S100 proteins in the pathogenesis of numerous diseases as highlighted in this review and mouse models suggest that genetic deletion has minimal effects on normal physiology, there is increasing interest in therapeutic targeting these proteins. Clinical trials to date have primarily focused on nonpulmonary diseases such as systemic lupus erythematosus (SLE), ischemic heart failure, and rheumatoid arthritis. We will discuss S100 inhibitors and clinical trials undertaken with these therapeutics to date (summarized in Table 2).

5.1. Clinical Trials to Date Utilizing the Quinoline-3Carboxamide Derivatives S100 Protein Inhibitors. In the past decade, several small molecules were identified to block the hydrophobic cleft required for the recognition of S100 targets and thus block their activity, such as paquinimod (ABR215757), tasquinimod (ABR-215050), and laquinimod (ABR-215062). They are quinoline-3-carboxamide derivatives that primarily block the interaction of S100A8 and S100A9 with RAGE and TLR4 $[165,166]$. Laquinimod, a derivative of linomide (Roquinimex), interferes with S100 and its receptor RAGE binding and is proposed as a treatment for multiple sclerosis [167]. Here, we will briefly outline several of the clinical outcomes utilizing these quinoline-3carboxamide derivatives S100 protein inhibitors primarily in prostate cancer, SLE, and multiple sclerosis. However, few studies in human clinical trials report their findings as of the time of this paper, and pulmonary outcomes are limited.

Phase II randomized, double-blind, placebo-controlled study in men with minimally symptomatic metastatic castrate-resistant prostate cancer (CRPC), tasquinimod improves progression-free survival in patients with metastatic castration-resistant, possibly by reducing the recruitment of MDSCs and inhibiting metastasis [168, 169]. However, when tasquinimod was studied in a global phase III randomized trial in men with bone CRPC and while it significantly improved radiographic progression-free survival, this did not result in an overall survival benefit [170]. A recent phase II study failed to demonstrate the clinical activity of tasquinimod in heavily pretreated patients with advanced hepatocellular, ovarian, renal cell, and gastric cancer, and many experienced adverse events such as fatigue, nausea, decreased appetite, and vomiting [171].

There are multiple published findings from clinical trials with laquinimod, most notably in multiple sclerosis populations. In a large, multicenter phase III clinical trial (ALLEGRO), laquinimod was well tolerated [172]. The most common adverse events were elevated liver enzymes $(3.6 \%$ on laquinimod, $0.4 \%$ on placebo), abdominal pain, back pain, and cough. However, another trial with laquinimod (BRAVO [173]) in patients with relapsing multiple sclerosis showed conflicting results with the efficacy of laquinimod in reducing relapses and MRI measures of inflammation of multiple sclerosis patients. Recently, laquinimod did not reach the primary endpoint of reduction in confirmed disability progression in a phase 3 trial of patients with relapsing multiple sclerosis [167].

Paquinimod is reported to be beneficial in several animal models including systemic sclerosis [174], COPD [110], type 1 diabetes [175], and SLE [176]. Recently, our group observed that treatment of cigarette exposed mice with paquinimod, an S100A9 inhibitor, could preserve lung function [110]. In an SLE-prone mouse study where the animals 
TABLE 2: Current drug development targeting S100 proteins.

\begin{tabular}{|c|c|c|c|c|}
\hline $\begin{array}{l}\text { Therapeutic } \\
\text { approach }\end{array}$ & Agent & Possible S100 protein interaction & Current status & Study \\
\hline \multirow{3}{*}{$\begin{array}{l}\text { Small molecule } \\
\text { inhibition of } \\
\text { S100 proteins } \\
\text { Quinoline-3- } \\
\text { carboxamide } \\
\text { derivatives }\end{array}$} & $\begin{array}{l}\text { Tasquinimod } \\
(\text { ABR-215050) }\end{array}$ & $\begin{array}{l}\text { Oral administration that blocks S100A8 and } \\
\text { S100A9 interacting with RAGE and TLR4 }\end{array}$ & $\begin{array}{l}\text { Phase II randomized, double-blind, placebo- } \\
\text { controlled studies in men with minimally } \\
\text { symptomatic metastatic CRPC }\end{array}$ & $\begin{array}{l}{[168-} \\
170]\end{array}$ \\
\hline & $\begin{array}{l}\text { Paquinimod } \\
(\text { ABR-215757) }\end{array}$ & $\begin{array}{l}\text { Oral administration that blocks } \\
\text { S100A8/S100A9 interacting with TLR4 }\end{array}$ & $\begin{array}{l}\text { Phase I study demonstrated good tolerance in } \\
\text { SLE patients, while a phase II study data never } \\
\text { published }\end{array}$ & $\begin{array}{l}{[176,} \\
177]\end{array}$ \\
\hline & $\begin{array}{l}\text { Laquinimod } \\
(\mathrm{ABR}-215062)\end{array}$ & $\begin{array}{l}\text { Oral administration that blocks S100A8 and } \\
\text { S100A9 interacting with RAGE and TLR4 }\end{array}$ & $\begin{array}{c}\text { Conflicting data in several multicenter phase II } \\
\text { and III clinical trials in multiple sclerosis } \\
\text { populations }\end{array}$ & $\begin{array}{l}{[167} \\
172 \\
173]\end{array}$ \\
\hline \multirow{3}{*}{$\begin{array}{l}\text { Inhibitors of } \\
\text { S100 proteins }\end{array}$} & $\begin{array}{l}\text { Cromolyn } \\
\text { (cromoglicic } \\
\text { acid) }\end{array}$ & $\begin{array}{l}\text { An antihistaminic drug binds to S100A1, } \\
\text { S10012, S100A13, and S100P and disrupts } \\
\text { interactions with RAGE }\end{array}$ & $\begin{array}{c}\text { FDA approved } 20 \text { years ago as an antihistaminic } \\
\text { drug, as a nasal spray (NasalCrom) }\end{array}$ & [178] \\
\hline & Amlexanox & $\begin{array}{l}\text { Interacts with } \mathrm{S} 100 \mathrm{~A} 1, \mathrm{~S} 100 \mathrm{~A} 4 \text {, and } \\
\text { S100A13 to prevent their signaling }\end{array}$ & $\begin{array}{l}\text { Used to treat recurrent aphthous ulcers but } \\
\text { discontinued in the USA } \\
\text { In Japan, it is used to treat bronchial asthma, } \\
\text { allergic rhinitis, and conjunctivitis }\end{array}$ & $\begin{array}{l}{[184]} \\
{[228]}\end{array}$ \\
\hline & $\begin{array}{l}\text { Phenothiazines, } \\
\text { such as } \\
\text { trifluoperazine }\end{array}$ & $\begin{array}{l}\text { Disrupt the interaction of S100A4 with } \\
\text { myosin-IIA }\end{array}$ & $\begin{array}{l}\text { Used to treat psychotic disorders, anxiety, } \\
\text { nausea, and vomiting caused by chemotherapy }\end{array}$ & [229] \\
\hline \multirow{5}{*}{$\begin{array}{l}\text { Indirect } \\
\text { inhibitors of } \\
\text { S100 protein } \\
\text { signaling }\end{array}$} & Pentamidine & $\begin{array}{l}\text { Downregulates inflammation mediated } \\
\qquad \mathrm{S} 100 \mathrm{~B}\end{array}$ & $\begin{array}{c}\text { An antimicrobial agent to treat African } \\
\text { trypanosomiasis, leishmaniasis, Balamuthia } \\
\text { infections, babesiosis, and Pneumocystis } \\
\text { pneumonia }\end{array}$ & [192] \\
\hline & Arundic acid & Reduces S100B levels & $\begin{array}{l}\text { A multicenter, dose-escalating, randomized, } \\
\text { double-blind phase I trial was performed in } \\
\text { acute ischemic stroke }\end{array}$ & $\begin{array}{l}{[194,} \\
230]\end{array}$ \\
\hline & $\begin{array}{l}\text { Calcimycin } \\
\text { (A23187) }\end{array}$ & Inhibit S100A4 expression & $\begin{array}{l}\text { A calcium ionophore used against gram-positive } \\
\text { bacteria and fungi. Also, in in vitro fertilization } \\
\text { and to make artificial liposomes for cancer drugs }\end{array}$ & [185] \\
\hline & $\begin{array}{l}\text { Niclosamide } \\
\text { (niclocide) }\end{array}$ & Inhibit S100A4 expression & Oral administered antihelminth drug & [231] \\
\hline & Sulindac & Inhibit S100A4 expression & A nonsteroidal anti-inflammatory drug & [186] \\
\hline $\begin{array}{l}\text { Gene delivery } \\
\text { approaches }\end{array}$ & $\begin{array}{l}\text { Adenoviral- } \\
\text { associated vector } \\
\text { S100A1 gene } \\
\text { delivery }\end{array}$ & $\begin{array}{c}\text { Restored S100A1 levels to restore } \\
\text { cardiomyocytes physiologic contractility, } \\
\text { cardiac performance, and left ventricular } \\
\text { remodeling }\end{array}$ & Only tested in animal models & $\begin{array}{l}{[201,} \\
202]\end{array}$ \\
\hline $\begin{array}{l}\text { S100 } \\
\text { neutralizing } \\
\text { antibodies }\end{array}$ & $\begin{array}{l}\text { Anti-S100A4, } \\
\text { anti-S100P, anti- } \\
\text { S100A9 }\end{array}$ & $\begin{array}{c}\text { Prevent extracellular signaling of } \mathrm{S} 100 \\
\text { proteins }\end{array}$ & Only tested in animal models & $\begin{array}{l}{[39} \\
195 \\
196]\end{array}$ \\
\hline $\begin{array}{l}\text { S100 } \\
\text { neutralizing } \\
\text { peptides }\end{array}$ & $\begin{array}{l}\text { Peptide-Fc fusion } \\
\text { proteins } \\
\text { (peptibody) }\end{array}$ & $\begin{array}{l}\text { Depletes myeloid-derived suppressor cells } \\
\text { getting to tumor and releasing S100 proteins }\end{array}$ & $\begin{array}{l}\text { Only tested in animal models but reduced tumor } \\
\text { growth }\end{array}$ & $\begin{array}{l}{[197,} \\
199]\end{array}$ \\
\hline $\begin{array}{l}\text { Vaccines } \\
\text { targeting S100 } \\
\text { proteins }\end{array}$ & $\begin{array}{l}\text { Anti-S100A9 } \\
\text { vaccine }\end{array}$ & $\begin{array}{l}\text { Prevent S100A9/CD36 signaling in a mouse } \\
\text { ischemic stroke model }\end{array}$ & Only tested in animal models & [200] \\
\hline
\end{tabular}

developed significant glomerulonephritis resulting in hematuria and proteinuria, treatment with paquinimod was comparable to prednisolone or mycophenolate treatment [176]. A phase $1 \mathrm{~b}$ study in humans demonstrates good tolerance of paquinimod at $3 \mathrm{mg} / \mathrm{kg}$, but several adverse events, such as arthralgia and myalgia, were reported with the highest dose levels of paquinimod $(4.5 \mathrm{mg} /$ day and $6.0 \mathrm{mg} /$ day $)$ [176]. However, although a phase 2 study was initiated, no results have been released as of the time of this paper [177].
5.2. Other Potential Therapeutic Intervention of S100 Proteins. Here, we will briefly outline some alternative approaches to target S100 proteins that could be applied to lung diseases. These include gene delivery approaches, inhibitory antibodies and peptides, vaccines, and chemical inhibitors (see Table 2). Several new compounds were recently identified specifically for S100 proteins that inhibit the interactions of S100P [178], S100A4 [179, 180], S100A9 [179], S100A10 [181], and S100B [182, 183] with their targets. 
The antihistaminic drug, cromolyn, binds to S100A1, S10012, S100A13, and S100P and disrupts S100P interacting with RAGE [178]. A cromolyn analog which inhibits S100P was used in pancreatic cell line and mice models to reduce tumor growth and metastasis [178]. Another antiinflammatory antiallergic immunomodulatory drug, Amlexanox, interacts with S100A1, S100A4, and S100A13 and alters S100 protein signal transduction [184]. Alternatively, phenothiazines interact with multiple S100 family members, such as S100A4 [22], and may influence their signaling.

Equally several compounds are known to inhibit the S100A4 expression, with calcimycin (a calcium ionophore), niclosamide (an antihelminth drug), and sulindac (a nonsteroidal anti-inflammatory drug) are all reported as inhibitors of S100A4 transcription $[185,186]$. Interestingly, calcimycin can augment surfactant secretion in cultured type II airway epithelial cells (AEC II) [187, 188]. Equally, niclosamide increases the sensitivity of cancer cells for radiation therapy in lung cancer [189] and alleviates pulmonary fibrosis in vitro and in vivo by attenuation of epithelial-tomesenchymal transition, matrix proteins, and $\mathrm{Wnt} / \beta$ catenin signaling [190]. Sulindac is also linked to lung cancer therapy and pulmonary fibrosis [191]. Whether these responses are due to S100A4 are unknown. Pentamidine is deemed an S100B inhibitor as it reduces several inflammatory markers such as MDA, PGE2, and IL-1, which in turn downregulated S100B [192]. By blocking S100B activity, pentamidine rescues expression of the tumor suppressor factor wtp53 and restores proapoptotic responses in colon cancer [193]. Alternatively, other groups have tried to reduce S100B levels, using arundic acid, and found that treatment with arundic acid at 24-48 hours after the induction of ischemia significantly decreased infarct volumes by approximately $40 \%$ [194].

Other approaches to modulate S100 protein activity include neutralizing antibodies $[39,195,196]$ and peptideFc fusion proteins (peptibodies) directed against S100A8 and S100A9 [197]. Antibody-based therapies are an interesting approach for several of the S100 proteins as they possibly could reduce toxicity and off-target effects but may be limited to only extracellular S100 proteins. Treatment with an antiS100A4 antibody decreased signs of allergy in a mouse model as well as in allergen-challenged $\mathrm{T}$ cells from allergic patients [198]. Inhibiting extracellular S100 protein signaling may be beneficial for COPD, as intracellular S100A8 protects against type II pneumocyte cytotoxicity [107], while extracellular S100A9 contributes to disease progression [110]. Some inhibitory peptides can penetrate cells with S100B inhibitory peptides reported to penetrate tumor cells and reduce growth in a melanoma xenograft model [199]. Immunization with an anti-S100A9 vaccine in a mouse ischemic stroke inhibited long-term thrombus formation, through inhibition of increased S100A9/CD36 signaling, without risk of bleeding or adverse autoimmune responses [200]. In rodent [201] and pig [202] cardiac disease models, adenoviral-associated vector S100A1 gene delivery to cardiac tissue normalized low S100A1 levels and restore cardiomyocytes physiologic contractility, restored cardiac performance, and left ventricular remodeling. Therefore, many approaches exist to modu- late S100 protein signaling but most require testing in the setting of pulmonary diseases.

\section{The Influence of Neutrophils in the Release of S100 Proteins in Pulmonary Diseases}

Finally, we want to briefly discuss the importance of S100 proteins and neutrophils in pulmonary diseases. Neutrophils are the first responders to the site of inflammation and are essential for microbial containment, eradication, and host survival. Dysregulated neutrophil responses are central to the pathophysiology of many inflammatory lung diseases. Approximately $45 \%$ of the cytosolic proteins in neutrophils are constituted with S100A8, S100A9, and S100A12 and are released upon injury or infection [203, 204]. Following activation of neutrophils, the $\mathrm{S} 100$ proteins are secreted or released and function in an autocrine and paracrine manner. The released S100 proteins induce the production of proinflammatory cytokines, neutrophil degranulation and chemotaxis, leukocyte adhesion and endothelial transmigration, and increased effects of lipopolysaccharide on phagocytes and cells (Figure 1). At the site of inflammation, calprotectin acts as a chemotactic factor by inducing neutrophils adhesion [159] and thereby further exaggerates neutrophil responses.

Rammes et al. have suggested that in monocytes, the nonclassical S100A8/A9 secretion constitutes an intact microtubule network and PKC activation [114]. However, in neutrophils, the process by which S100A8/A9 is secreted is not fully elucidated and may be different from the pathway in monocytes since the S100A8/A9 complex is detected in NETs. Secretion of S100A8/A9 is dependent on the production of ROS and required $\mathrm{K}^{+}$exchanges through the ATPsensitive $\mathrm{K}^{+}$channel [205]. Schenten et al. indicated that S100A9 is phosphorylated at threonine 113 by the MAPK p38 in activated neutrophils and released to the extracellular space by the process of NETosis [27, 206, 207]. Equally, S100A9 is an activator of the $\beta-2$ integrin Mac-1 (CD11b/CD18) on neutrophils [208] and could influence neutrophil trafficking, phagocytosis, ROS production, and $\mathrm{T}$ cell activation [209]. However, further research is needed to elucidate the signaling pathway.

With the new human viral disease severe acute respiratory syndrome coronavirus 2 (SARS-CoV-2), there is emerging data identifying the roles of $\mathrm{S} 100$ proteins to coronavirus disease 2019 (COVID-19). In preclinical models of SARS$\mathrm{CoV}-2$ infected animals and patients, there are increased levels of immature neutrophils and dramatically upregulated S100A8 levels [210]. In addition, multivariable analysis of patients' samples demonstrated that elevated S100A9 was independently associated with mortality [211]. Serum S100A8/A9 levels in COVID-19 patients are linked to severity and in-hospital mortality [212] and early indicator of respiratory failure [210]. This suggests that S100 proteins of neutrophil origin could significantly contribute to inflammation and respiratory outcomes in COVID-19 subjects. Higher blood frequency of NETs and neutrophil activation markers including S100A8/A9 are observed in COVID-19 cases associated with thrombosis [213] and in COVID-19 with severe pulmonary outcomes [214]. The presence of S100A8/A9 in 
fecal is linked to intestinal inflammation in COVID-19 patients $[215,216]$. Equally, monocytes with low expression of HLA-DR and high expression of S100A8, A9, and 12 are strongly associated with severe COVID-19 [137]. Serum S100B COVID-19 patients significantly correlate with disease severity and are associated with inflammation markers (ferritin, C-reactive protein, procalcitonin) and organ damage markers (alanine aminotransferase, creatinine) [217]. Recently, paquinimod was shown to resolve SARS-CoV-2 mediated pneumonia by reducing the viral load and a subset of neutrophils in mice [218]. Therefore, neutrophilassociated S100 proteins may represent key players in the pathogenesis of many pulmonary diseases, including COVID-19.

\section{Conclusions}

In the past two decades, our knowledge of the roles of S100 proteins in pulmonary diseases has grown, and many novel approaches were identified to target members of this protein family as therapeutic options. Despite considerable progress in S100 protein biology, we still know little about posttranslational modifications or heterodimer formation impact on S100 signaling, and the COVID-19 pandemic highlights the potential role of $\mathrm{S} 100$ proteins in tissue damage.

\section{Conflicts of Interest}

The authors declare that there is no conflict of interest regarding the publication of this article.

\section{Acknowledgments}

This work was supported by grants made available to P.G. (the Alpha-1 Foundation (493373 and 614218)).

\section{References}

[1] M. E. Bianchi, "DAMPs, PAMPs and alarmins: all we need to know about danger," Journal of Leukocyte Biology, vol. 81, no. 1, pp. 1-5, 2007.

[2] T. Gong, L. Liu, W. Jiang, and R. Zhou, "DAMP-sensing receptors in sterile inflammation and inflammatory diseases," Nature Reviews. Immunology, vol. 20, no. 2, pp. 95-112, 2020.

[3] E. Leclerc, G. Fritz, S. W. Vetter, and C. W. Heizmann, "Binding of S100 proteins to RAGE: an update," Biochimica et Biophysica Acta, vol. 1793, no. 6, pp. 993-1007, 2009.

[4] R. Donato, B. R. Cannon, G. Sorci et al., "Functions of S100 proteins," Current Molecular Medicine, vol. 13, no. 1, pp. 24-57, 2013.

[5] S. R. Gross, C. G. Sin, R. Barraclough, and P. S. Rudland, "Joining S100 proteins and migration: for better or for worse, in sickness and in health," Cellular and Molecular Life Sciences, vol. 71, no. 9, pp. 1551-1579, 2014.

[6] R. Donato, "Intracellular and extracellular roles of S100 proteins," Microscopy Research and Technique, vol. 60, no. 6, pp. 540-551, 2003.

[7] B. W. Moore, "A soluble protein characteristic of the nervous system," Biochemical and Biophysical Research Communications, vol. 19, no. 6, pp. 739-744, 1965.
[8] N. Kozlyuk, A. J. Monteith, V. Garcia, S. M. Damo, E. P. Skaar, and W. J. Chazin, "S100 proteins in the innate immune response to pathogens," Methods in Molecular Biology, vol. 1929, pp. 275-290, 2019.

[9] I. Marenholz, C. W. Heizmann, and G. Fritz, "S100 proteins in mouse and man: from evolution to function and pathology (including an update of the nomenclature)," Biochemical and Biophysical Research Communications, vol. 322, no. 4, pp. 1111-1122, 2004.

[10] L. L. Gonzalez, K. Garrie, and M. D. Turner, "Role of S100 proteins in health and disease," Biochimica et Biophysica Acta (BBA)-Molecular Cell Research, vol. 1867, no. 6, p. 118677, 2020.

[11] B. A. Gilston, E. P. Skaar, and W. J. Chazin, "Binding of transition metals to S100 proteins," Science China. Life Sciences, vol. 59, no. 8, pp. 792-801, 2016.

[12] T. G. Nakashige, B. Zhang, C. Krebs, and E. M. Nolan, "Human calprotectin is an iron-sequestering host-defense protein," Nature Chemical Biology, vol. 11, no. 10, pp. 765$771,2015$.

[13] D. Foell, H. Wittkowski, T. Vogl, and J. Roth, "S100 proteins expressed in phagocytes: a novel group of damage-associated molecular pattern molecules," Journal of Leukocyte Biology, vol. 81, no. 1, pp. 28-37, 2007.

[14] C. Xia, Z. Braunstein, A. C. Toomey, J. Zhong, and X. Rao, "S100 proteins as an important regulator of macrophage inflammation," Frontiers in Immunology, vol. 8, p. 1908, 2018.

[15] C. R. Silva, B. M. S. Melo, J. R. Silva et al., "S100A9 plays a pivotal role in a mouse model of herpetic neuralgia via TLR4/TNF pathway," Brain, Behavior, and Immunity, vol. 88, pp. 353-362, 2020.

[16] M. A. Hofmann, S. Drury, C. Fu et al., "RAGE mediates a novel proinflammatory axis: a central cell surface receptor for S100/calgranulin polypeptides," Cell, vol. 97, no. 7, pp. 889-901, 1999.

[17] M. B. Brophy, J. A. Hayden, and E. M. Nolan, "Calcium ion gradients modulate the zinc affinity and antibacterial activity of human calprotectin," Journal of the American Chemical Society, vol. 134, no. 43, pp. 18089-18100, 2012.

[18] G. Fritz, H. M. Botelho, L. A. Morozova-Roche, and C. M. Gomes, "Natural and amyloid self-assembly of $\$ 100$ proteins: structural basis of functional diversity," The FEBS Journal, vol. 277, no. 22, pp. 4578-4590, 2010.

[19] M. Ichikawa, R. Williams, L. Wang, T. Vogl, and G. Srikrishna, "S100A8/A9 activate key genes and pathways in colon tumor progression," Molecular Cancer Research, vol. 9, no. 2, pp. 133-148, 2011.

[20] N. T. Wright, B. R. Cannon, P. T. Wilder et al., "Solution structure of S100A1 bound to the CapZ peptide (TRTK12)," Journal of Molecular Biology, vol. 386, no. 5, pp. 1265-1277, 2009.

[21] J. Markowitz, R. R. Rustandi, K. M. Varney et al., "Calciumbinding properties of wild-type and EF-hand mutants of $\mathrm{S} 100 \mathrm{~B}$ in the presence and absence of a peptide derived from the C-terminal negative regulatory domain of $\mathrm{p} 53$," Biochemistry, vol. 44, no. 19, pp. 7305-7314, 2005.

[22] V. N. Malashkevich, K. M. Varney, S. C. Garrett et al., "Structure of $\mathrm{Ca} 2+-$-bound S100A4 and its interaction with peptides derived from nonmuscle myosin-IIA," Biochemistry, vol. 47, no. 18, pp. 5111-5126, 2008. 
[23] U. A. Ramagopal, N. G. Dulyaninova, K. M. Varney et al., "Structure of the S100A4/myosin-IIA complex," BMC Structural Biology, vol. 13, no. 1, p. 31, 2013.

[24] L. M. Orre, M. Pernemalm, J. Lengqvist, R. Lewensohn, and J. Lehtiö, "Up-regulation, modification, and translocation of S100A6 induced by exposure to ionizing radiation revealed by proteomics profiling," Molecular \& Cellular Proteomics, vol. 6, no. 12, pp. 2122-2131, 2007.

[25] K. J. Miranda, R. F. Loeser, and R. R. Yammani, "Sumoylation and nuclear translocation of S100A4 regulate IL-1 $\beta$-mediated production of matrix metalloproteinase-13," The Journal of Biological Chemistry, vol. 285, no. 41, pp. 31517-31524, 2010.

[26] S. Y. Lim, M. Raftery, H. Cai et al., "S-nitrosylated S100A8: novel anti-inflammatory properties," Journal of Immunology, vol. 181, no. 8, pp. 5627-5636, 2008.

[27] V. Schenten, S. Plançon, N. Jung et al., "Secretion of the phosphorylated form of S100A9 from neutrophils is essential for the proinflammatory functions of extracellular S100A8/A9," Frontiers in Immunology, vol. 9, p. 447, 2018.

[28] L. S. Cunden, M. B. Brophy, G. E. Rodriguez, H. A. Flaxman, and E. M. Nolan, "Biochemical and functional evaluation of the intramolecular disulfide bonds in the zinc-chelating antimicrobial protein human S100A7 (psoriasin)," Biochemistry, vol. 56, no. 43, pp. 5726-5738, 2017.

[29] D. L. Cecil and R. Terkeltaub, "Transamidation by transglutaminase 2 transforms S100A11 calgranulin into a procatabolic cytokine for chondrocytes," Journal of Immunology, vol. 180, no. 12, pp. 8378-8385, 2008.

[30] W. J. Chazin, "Relating form and function of EF-hand calcium binding proteins," Accounts of Chemical Research, vol. 44, no. 3, pp. 171-179, 2011.

[31] M. Pedrocchi, B. W. Schäfer, H. Mueller, U. Eppenberger, and C. W. Heizmann, "Expression of $\mathrm{ca}(2+)$-binding proteins of the S100 family in malignant human breast-cancer cell lines and biopsy samples," International Journal of Cancer, vol. 57, no. 5, pp. 684-690, 1994.

[32] J. T. Elder and X. Zhao, "Evidence for local control of gene expression in the epidermal differentiation complex," Experimental Dermatology, vol. 11, no. 5, pp. 406-412, 2002.

[33] S. S. Cross, F. C. Hamdy, J. C. Deloulme, and I. Rehman, "Expression of S100 proteins in normal human tissues and common cancers using tissue microarrays: S100A6, S100A8, S100A9 and S100A11 are all overexpressed in common cancers," Histopathology, vol. 46, no. 3, pp. 256-269, 2005.

[34] J. C. Lindsey, M. E. Lusher, J. A. Anderton, R. J. Gilbertson, D. W. Ellison, and S. C. Clifford, "Epigenetic deregulation of multiple S100 gene family members by differential hypomethylation and hypermethylation events in medulloblastoma," British Journal of Cancer, vol. 97, no. 2, pp. 267-274, 2007.

[35] Q. Wang, M. Williamson, S. Bott et al., "Hypomethylation of WNT5A, CRIP1 and S100P in prostate cancer," Oncogene, vol. 26, no. 45, pp. 6560-6565, 2007.

[36] W. Lesniak, "Epigenetic regulation of S100 protein expression," Clinical Epigenetics, vol. 2, no. 2, pp. 77-83, 2011.

[37] K. Hsu, C. Champaiboon, B. D. Guenther et al., "Anti-infective protective properties of $\mathrm{S} 100$ calgranulins," AntiInflammatory \& Anti-Allergy Agents in Medicinal Chemistry (Formerly Current Medicinal Chemistry-AntiInflammatory and Anti-Allergy Agents), vol. 8, no. 4, pp. 290-305, 2009.
[38] M. A. Ingersoll, R. Spanbroek, C. Lottaz et al., "Comparison of gene expression profiles between human and mouse monocyte subsets," Blood, vol. 115, no. 3, pp. e10-e19, 2010.

[39] R. F. Foronjy, P. O. Ochieng, M. A. Salathe et al., "Protein tyrosine phosphatase $1 \mathrm{~B}$ negatively regulates S100A9mediated lung damage during respiratory syncytial virus exacerbations," Mucosal Immunology, vol. 9, no. 5, pp. 1317-1329, 2016.

[40] J. A. Spijkers-Hagelstein, P. Schneider, E. Hulleman et al., "Elevated S100A8/S100A9 expression causes glucocorticoid resistance in MLL-rearranged infant acute lymphoblastic leukemia," Leukemia, vol. 26, no. 6, pp. 1255-1265, 2012.

[41] C. Li, F. Zhang, M. Lin, and J. Liu, "Induction of S100A9 gene expression by cytokine oncostatin $\mathrm{M}$ in breast cancer cells through the STAT3 signaling cascade," Breast Cancer Research and Treatment, vol. 87, no. 2, pp. 123-134, 2004.

[42] A. C. Tramontina, F. Tramontina, L. D. Bobermin et al., "Secretion of S100B, an astrocyte-derived neurotrophic protein, is stimulated by fluoxetine via a mechanism independent of serotonin," Progress in Neuro-Psychopharmacology \& Biological Psychiatry, vol. 32, no. 6, pp. 1580-1583, 2008.

[43] D. F. de Souza, M. C. Leite, A. Quincozes-Santos et al., "S100B secretion is stimulated by IL- $1 \beta$ in glial cultures and hippocampal slices of rats: likely involvement of MAPK pathway," Journal of Neuroimmunology, vol. 206, no. 1-2, pp. 5257, 2009.

[44] P. Nardin, L. Tortorelli, A. Quincozes-Santos et al., "S100B secretion in acute brain slices: modulation by extracellular levels of $\mathrm{Ca}(2+)$ and $\mathrm{K}(+), "$ Neurochemical Research, vol. 34, no. 9, pp. 1603-1611, 2009.

[45] K. M. Kathir, K. Ibrahim, D. Rajalingam, I. Prudovsky, C. Yu, and T. K. S. Kumar, "S100A13-lipid interactions-role in the non-classical release of the acidic fibroblast growth factor," Biochimica et Biophysica Acta, vol. 1768, no. 12, pp. 30803089, 2007.

[46] M. Kapoor, Q. Zhou, F. Otero et al., "Evidence for annexin IIS100A10 complex and plasmin in mobilization of cytokine activity of human TrpRS," The Journal of Biological Chemistry, vol. 283, no. 4, pp. 2070-2077, 2008.

[47] T. Vogl, S. Ludwig, M. Goebeler et al., "MRP8 and MRP14 control microtubule reorganization during transendothelial migration of phagocytes," Blood, vol. 104, no. 13, pp. 42604268, 2004.

[48] T. Vogl, K. Tenbrock, S. Ludwig et al., "Mrp8 and Mrp14 are endogenous activators of toll-like receptor 4, promoting lethal, endotoxin-induced shock," Nature Medicine, vol. 13, no. 9, pp. 1042-1049, 2007.

[49] O. Turovskaya, D. Foell, P. Sinha et al., "RAGE, carboxylated glycans and S100A8/A9 play essential roles in colitisassociated carcinogenesis," Carcinogenesis, vol. 29, no. 10, pp. 2035-2043, 2008.

[50] C. Gebhardt, A. Riehl, M. Durchdewald et al., "RAGE signaling sustains inflammation and promotes tumor development," The Journal of Experimental Medicine, vol. 205, no. 2, pp. 275-285, 2008.

[51] S. Ghavami, I. Rashedi, B. M. Dattilo et al., "S100A8/A9 at low concentration promotes tumor cell growth via RAGE ligation and MAP kinase-dependent pathway," Journal of Leukocyte Biology, vol. 83, no. 6, pp. 1484-1492, 2008.

[52] E. Leclerc, G. Fritz, M. Weibel, C. W. Heizmann, and A. Galichet, "S100B and S100A6 differentially modulate cell 
survival by interacting with distinct RAGE (receptor for advanced glycation end products) immunoglobulin domains," The Journal of Biological Chemistry, vol. 282, no. 43, pp. 31317-31331, 2007.

[53] G. Sorci, F. Riuzzi, C. Arcuri, I. Giambanco, and R. Donato, "Amphoterin stimulates myogenesis and counteracts the antimyogenic factors basic fibroblast growth factor and S100B via RAGE binding," Molecular and Cellular Biology, vol. 24, no. 11, pp. 4880-4894, 2004.

[54] C. Tondera, M. Laube, and J. Pietzsch, "Insights into binding of S100 proteins to scavenger receptors: class B scavenger receptor CD36 binds S100A12 with high affinity," Amino Acids, vol. 49, no. 1, pp. 183-191, 2017.

[55] F. Riuzzi, G. Sorci, and R. Donato, "S100B protein regulates myoblast proliferation and differentiation by activating FGFR1 in a bFGF-dependent manner," Journal of Cell Science, vol. 124, no. 14, pp. 2389-2400, 2011.

[56] R. von Bauer, D. Oikonomou, A. Sulaj et al., "CD166/ALCAM mediates proinflammatory effects of S100B in delayed type hypersensitivity," Journal of Immunology, vol. 191, no. 1, pp. 369-377, 2013.

[57] O. Dmytriyeva, S. Pankratova, S. Owczarek et al., "The metastasis-promoting S100A4 protein confers neuroprotection in brain injury," Nature Communications, vol. 3, no. 1, p. 1197, 2012.

[58] M. Sakaguchi, M. Yamamoto, M. Miyai et al., "Identification of an S100A8 receptor neuroplastin- $\beta$ and its heterodimer formation with EMMPRIN," The Journal of Investigative Dermatology, vol. 136, no. 11, pp. 2240-2250, 2016.

[59] K. Okada, S. Arai, H. Itoh et al., "CD68 on rat macrophages binds tightly to S100A8 and S100A9 and helps to regulate the cells' immune functions," Journal of Leukocyte Biology, vol. 100, no. 5, pp. 1093-1104, 2016.

[60] S. Pankratova, J. Klingelhofer, O. Dmytriyeva et al., "The S100A4 protein signals through the ErbB4 receptor to promote neuronal survival," Theranostics, vol. 8, no. 14, pp. 3977-3990, 2018.

[61] K. Teichert-Kuliszewska, J. N. Tsoporis, J. F. Desjardins et al., "Absence of the calcium-binding protein, S100A1, confers pulmonary hypertension in mice associated with endothelial dysfunction and apoptosis," Cardiovascular Research, vol. 105, no. 1, pp. 8-19, 2015.

[62] J.-F. Desjardins, A. Pourdjabbar, A. Quan et al., "Lack of S100A1 in mice confers a gender-dependent hypertensive phenotype and increased mortality after myocardial infarction," American Journal of Physiology-Heart and Circulatory Physiology, vol. 296, no. 5, pp. H1457-H1465, 2009.

[63] S. T. Pleger, D. M. Harris, C. Shan et al., "Endothelial S100A1 modulates vascular function via nitric oxide," Circulation Research, vol. 102, no. 7, pp. 786-794, 2008.

[64] P. Ehlermann, A. Remppis, O. Guddat et al., "Right ventricular upregulation of the $\mathrm{Ca}^{2+}$ binding protein S100A1 in chronic pulmonary hypertension," Biochimica et Biophysica Acta, vol. 1500, no. 2, pp. 249-255, 2000.

[65] S. Wolf, C. Haase-Kohn, and J. Pietzsch, "S100A2 in cancerogenesis: a friend or a foe?," Amino Acids, vol. 41, no. 4, pp. 849-861, 2011.

[66] A. V. Biankin, J. G. Kench, E. K. Colvin et al., "Expression of S100A2 calcium-binding protein predicts response to pancreatectomy for pancreatic cancer," Gastroenterology, vol. 137, no. 2, pp. 558-568.e11, 2009.
[67] K. Ohuchida, K. Mizumoto, Y. Miyasaka et al., "Over-expression of S100A2 in pancreatic cancer correlates with progression and poor prognosis," The Journal of Pathology: A Journal of the Pathological Society of Great Britain and Ireland, vol. 213, no. 3, pp. 275-282, 2007.

[68] G. Feng, X.-c. Xu, E. M. Youssef, and R. Lotan, "Diminished expression of S100A2, a putative tumor suppressor, at early stage of human lung carcinogenesis," Cancer Research, vol. 61, no. 21, pp. 7999-8004, 2001.

[69] C. A. Moskaluk, M. K. Abdrabbo, J. Harper et al., "Gastric cancers overexpress S100A calcium-binding proteins," Cancer Research, vol. 62, no. 23, pp. 6823-6826, 2002.

[70] H. Wang, Z. Zhang, R. Li et al., "Overexpression of S100A2 protein as a prognostic marker for patients with stage I non small cell lung cancer," International Journal of Cancer, vol. 116, no. 2, pp. 285-290, 2005.

[71] K. Lee, S. T. Yun, C. O. Yun, B. Y. Ahn, and E. C. Jo, "S100A2 promoter-driven conditionally replicative adenovirus targets non- small-cell lung carcinoma," Gene Therapy, vol. 19, no. 10, pp. 967-977, 2012.

[72] E. A. al-Mutairy, F. A. Imtiaz, M. Khalid et al., "An atypical pulmonary fibrosis is associated with co-inheritance of mutations in the calcium binding protein genesS100A3andS100A13," European Respiratory Journal, vol. 54, no. 1, article 1802041, 2019.

[73] M. Gianni, M. Li Calzi, M. Terao et al., "AM580, a stable benzoic derivative of retinoic acid, has powerful and selective cyto-differentiating effects on acute promyelocytic leukemia cells," 1996.

[74] M. Gianni, M. Terao, M. Kurosaki et al., "S100A3 a partner protein regulating the stability/activity of RAR $\alpha$ and PMLRAR $\alpha$ in cellular models of breast/lung cancer and acute myeloid leukemia," Oncogene, vol. 38, no. 14, pp. 24822500, 2019.

[75] S. Miao, T. Qiu, Y. Zhao et al., "Overexpression of S100A13 protein is associated with tumor angiogenesis and poor survival in patients with early-stage non-small cell lung cancer," Thoracic cancer, vol. 9, no. 9, pp. 1136-1144, 2018.

[76] A. Pierce, N. Barron, R. Linehan et al., "Identification of a novel, functional role for S100A13 in invasive lung cancer cell lines," European Journal of Cancer, vol. 44, no. 1, pp. 151159, 2008.

[77] W. Zhang, S. Ohno, B. Steer et al., "S100a4 is secreted by alternatively activated alveolar macrophages and promotes activation of lung fibroblasts in pulmonary fibrosis," Frontiers in Immunology, vol. 9, p. 1216, 2018.

[78] Y. Li, J. Bao, Y. Bian et al., "S100A4(+) macrophages are necessary for pulmonary fibrosis by activating lung fibroblasts," Frontiers in Immunology, vol. 9, p. 1776, 2018.

[79] S. Hou, T. Tian, D. Qi et al., "S100A4 promotes lung tumor development through $\beta$-catenin pathway-mediated autophagy inhibition," Cell Death \& Disease, vol. 9, no. 3, p. 277, 2018.

[80] D. C. Rubinsztein, G. Mariño, and G. Kroemer, "Autophagy and aging," Cell, vol. 146, no. 5, pp. 682-695, 2011.

[81] N. Mizushima and M. Komatsu, "Autophagy: renovation of cells and tissues,” Cell, vol. 147, no. 4, pp. 728-741, 2011.

[82] L. Liu, L. Qi, T. Knifley et al., "S100A4 alters metabolism and promotes invasion of lung cancer cells by up- regulating mitochondrial complex I protein NDUFS2," The Journal of Biological Chemistry, vol. 294, no. 18, pp. 7516-7527, 2019. 
[83] C. el Naaman, B. Grum-Schwensen, A. Mansouri et al., "Cancer predisposition in mice deficient for the metastasisassociated Mts1(S100A4) gene," Oncogene, vol. 23, no. 20, pp. 3670-3680, 2004.

[84] Y. Liu, J. Cui, Y.-L. Tang, L. Huang, C. Y. Zhou, and J. X. Xu, "Prognostic roles of mRNA expression of S100 in non-smallcell lung cancer," BioMed Research International, vol. 2018, Article ID 9815806, 11 pages, 2018.

[85] J. Sotty, G. Garçon, F. O. Denayer et al., "Toxicological effects of ambient fine $\left(\mathrm{PM}_{2.5-0.18}\right)$ and ultrafine $\left(\mathrm{PM}_{0.18}\right)$ particles in healthy and diseased 3D organo-typic mucocilary-phenotype models," Environmental Research, vol. 176, p. 108538, 2019.

[86] R. Donato, G. Sorci, and I. Giambanco, "S100A6 protein: functional roles," Cellular and Molecular Life Sciences, vol. 74, no. 15, pp. 2749-2760, 2017.

[87] T. Wang, Y. Liang, A. Thakur et al., "Diagnostic significance of S100A2 and S100A6 levels in sera of patients with nonsmall cell lung cancer," Tumor Biology, vol. 37, no. 2, pp. 2299-2304, 2016.

[88] X. He, X. Xu, A. Q. Khan, and W. Ling, "High expression of S100A6 predicts unfavorable prognosis of lung squamous cell cancer," Medical Science Monitor: International Medical Journal of Experimental and Clinical Research, vol. 23, pp. 5011-5017, 2017.

[89] A. Graczyk, Ł. P. Słomnicki, and W. Leśniak, "S100A6 competes with the TAZ2 domain of p300 for binding to p53 and attenuates p53 acetylation," Journal of Molecular Biology, vol. 425, no. 18, pp. 3488-3494, 2013.

[90] P. Li, X. Lv, Z. Zhang, and S. Xie, "S100A6/miR193a regulates the proliferation, invasion, migration and angiogenesis of lung cancer cells through the P53 acetylation," American Journal of Translational Research, vol. 11, no. 8, pp. 46344649, 2019.

[91] T. H. M. Grahn, A. Niroula, Á. Végvári et al., "S100A6 is a critical regulator of hematopoietic stem cells," Leukemia, vol. 34, no. 12, pp. 3323-3337, 2020.

[92] S. P. Zhang, Y. W. Wu, Z. Z. Wu, H. Y. Liu, J. H. Nie, and J. Tong, "Up-regulation of RAGE and S100A6 in rats exposed to cigarette smoke," Environmental Toxicology and Pharmacology, vol. 28, no. 2, pp. 259-264, 2009.

[93] C. Guilbault, J. P. Novak, P. Martin et al., "Distinct pattern of lung gene expression in the Cftr-KO mice developing spontaneous lung disease compared with their littermate controls," Physiological Genomics, vol. 25, no. 2, pp. 179-193, 2006.

[94] C. Landi, E. Bargagli, A. Carleo et al., "Bronchoalveolar lavage proteomic analysis in pulmonary fibrosis associated with systemic sclerosis: S100A6 and $14-3-3 \varepsilon$ as potential biomarkers," Rheumatology (Oxford), vol. 58, no. 1, pp. 165-178, 2019.

[95] M. Doubková, M. Karpisek, J. Mazoch, J. Skrickova, and M. Doubek, "Prognostic significance of surfactant protein A, surfactant protein D, Clara cell protein 16, S100 protein, trefoil factor 3, and prostatic secretory protein 94 in idiopathic pulmonary fibrosis, sarcoidosis, and chronic pulmonary obstructive disease," Sarcoidosis, Vasculitis, and Diffuse Lung Diseases, vol. 33, no. 3, pp. 224-234, 2016.

[96] B. D. Hardas, X. Zhao, J. Zhang, X. Longqing, S. Stoll, and J. T. Elder, "Assignment of psoriasin to human chromosomal band 1q21: coordinate overexpression of clustered genes is psoriasis," The Journal of Investigative Dermatology, vol. 106, no. 4, pp. 753-758, 1996.
[97] S. Semprini, F. Capon, S. Bovolenta et al., "Genomic structure, promoter characterisation and mutational analysis of the S100A7 gene: exclusion of a candidate for familial psoriasis susceptibility," Human Genetics, vol. 104, no. 2, pp. 130-134, 1999.

[98] Z. Lu, Y. Li, Y. Che et al., "The TGF $\beta$-induced lncRNA TBILA promotes non-small cell lung cancer progression in vitro and in vivo via cis-regulating HGAL and activating S100A7/JAB1 signaling," Cancer Letters, vol. 432, pp. 156$168,2018$.

[99] D. Pennino, P. K. Bhavsar, R. Effner et al., "IL-22 suppresses IFN- $\gamma$-mediated lung inflammation in asthmatic patients," Journal of Allergy and Clinical Immunology, vol. 131, no. 2, pp. 562-570, 2013.

[100] D. K. Kim, Y. C. Wi, S. J. Shin, K. R. Kim, D. W. Kim, and S. H. Cho, "Diverse phenotypes and endotypes of fungus balls caused by mixed bacterial colonization in chronic rhinosinusitis," International forum of allergy \& rhinology, vol. 9, no. 11, pp. 1360-1366, 2019.

[101] C. Baldini, L. Giusti, L. Bazzichi et al., "Association of psoriasin (S100A7) with clinical manifestations of systemic sclerosis: is its presence in whole saliva a potential predictor of pulmonary involvement?," The Journal of Rheumatology, vol. 35, no. 9, pp. 1820-1824, 2008.

[102] E. Andresen, C. Lange, D. Strodthoff et al., "S100A7/psoriasin expression in the human lung: unchanged in patients with COPD, but upregulated upon positive S. aureusdetection," BMC Pulmonary Medicine, vol. 11, no. 1, pp. 10-10, 2011.

[103] T. Jinquan, H. Vorum, C. G. Larsen et al., "Psoriasin: a novel chemotactic protein," Journal of Investigative Dermatology, vol. 107, no. 1, pp. 5-10, 1996.

[104] R. Gläser, J. Harder, H. Lange, J. Bartels, E. Christophers, and J. M. Schröder, "Antimicrobial psoriasin (S100A7) protects human skin from Escherichia coli infection," Nature Immunology, vol. 6, no. 1, pp. 57-64, 2005.

[105] R. Wang, Y. Li, E. Hu et al., "S100A7 promotes lung adenocarcinoma to squamous carcinoma transdifferentiation, and its expression is differentially regulated by the Hippo-YAP pathway in lung cancer cells," Oncotarget, vol. 8, no. 15, pp. 24804-24814, 2017.

[106] G. Liu, Q. Wu, G. Liu, X. Song, and J. Zhang, "RETRACTED ARTICLE: Psoriasin (S100A7) is a novel biomarker for lung squamous cell carcinoma in humans," Cancer Cell International, vol. 15, no. 1, p. 18, 2015.

[107] C. R. Lin, K. Bahmed, G. J. Criner et al., "S100A8 protects human primary alveolar type II cells against injury and emphysema," American Journal of Respiratory Cell and Molecular Biology, vol. 60, no. 3, pp. 299-307, 2019.

[108] S. J. Huang, Z. N. Ding, H. X. Xiang, L. Fu, and J. Fei, “Association between serum S100A8/S100A9 heterodimer and pulmonary function in patients with acute exacerbation of chronic obstructive pulmonary disease," Lung, vol. 198, no. 4, pp. 645-652, 2020.

[109] X. Huang, Y. Li, X. Guo et al., "Identification of differentially expressed genes and signaling pathways in chronic obstructive pulmonary disease via bioinformatic analysis," FEBS Open Bio, vol. 9, no. 11, pp. 1880-1899, 2019.

[110] C. Railwah, A. Lora, K. Zahid et al., "Cigarette smoke induction of S100A9 contributes to chronic obstructive pulmonary disease," American Journal of Physiology. Lung Cellular and Molecular Physiology, vol. 319, no. 6, pp. L1021-L1035, 2020. 
[111] Y. Hiroshima, K. Hsu, N. Tedla et al., "S100A8 induces IL-10 and protects against acute lung injury," The Journal of Immunology, vol. 192, no. 6, pp. 2800-2811, 2014.

[112] Y. Hiroshima, K. Hsu, N. Tedla et al., "S100A8/A9 and S100A9 reduce acute lung injury," Immunology and Cell Biology, vol. 95, no. 5, pp. 461-472, 2017.

[113] R. Gopal, L. Monin, D. Torres et al., "S100A8/A9 proteins mediate neutrophilic inflammation and lung pathology during tuberculosis," American Journal of Respiratory and Critical Care Medicine, vol. 188, no. 9, pp. 1137-1146, 2013.

[114] A. Rammes, J. Roth, M. Goebeler, M. Klempt, M. Hartmann, and C. Sorg, "Myeloid-related protein (MRP) 8 and MRP14, calcium-binding proteins of the $\mathrm{S} 100$ family, are secreted by activated monocytes via a novel, tubulin- dependent pathway," Journal of Biological Chemistry, vol. 272, no. 14, pp. 9496-9502, 1997.

[115] A. Voganatsi, A. Panyutich, K. T. Miyasaki, and R. K. Murthy, "Mechanism of extracellular release of human neutrophil calprotectin complex," Journal of Leukocyte Biology, vol. 70, no. 1, pp. 130-134, 2001.

[116] N. R. Scott, R. V. Swanson, N. al-Hammadi et al., "S100A8/A9 regulates CD11b expression and neutrophil recruitment during chronic tuberculosis," The Journal of Clinical Investigation, vol. 130, no. 6, pp. 3098-3112, 2020.

[117] D. H. Kim, E. Choi, J. S. Lee et al., "House dust mite allergen regulates constitutive apoptosis of normal and asthmatic neutrophils via toll-like receptor 4," PLoS One, vol. 10, no. 5, article $\mathrm{e} 0125983,2015$.

[118] D. H. Kim, A. Gu, J. S. Lee et al., "Suppressive effects of S100A8 and S100A9 on neutrophil apoptosis by cytokine release of human bronchial epithelial cells in asthma," International Journal of Medical Sciences, vol. 17, no. 4, pp. 498509, 2020.

[119] C. H. Wang, T. H. Punde, C. D. Huang et al., "Fibrocyte trafficking in patients with chronic obstructive asthma and during an acute asthma exacerbation," The Journal of Allergy and Clinical Immunology, vol. 135, no. 5, pp. 1154-1162.e5, 2015.

[120] L. D. Palmer, K. N. Maloney, K. L. Boyd et al., "The innate immune protein S100A9 protects from T-helper cell type 2mediated allergic airway inflammation," American Journal of Respiratory Cell and Molecular Biology, vol. 61, no. 4, pp. 459-468, 2019.

[121] T. Saito, M. Liu, M. Binnie et al., "Distinct expression patterns of alveolar "alarmins" in subtypes of chronic lung allograft dysfunction," American Journal of Transplantation, vol. 14, no. 6, pp. 1425-1432, 2014.

[122] G. Luo, M. Tang, Q. Zhao et al., "Bone marrow adipocytes enhance osteolytic bone destruction by activating 1q21.3(S100A7/8/9-IL6R)-TLR4 pathway in lung cancer," Journal of Cancer Research and Clinical Oncology, vol. 146, no. 9, pp. 2241-2253, 2020.

[123] A. Carleo, C. Landi, A. Prasse et al., "Proteomic characterization of idiopathic pulmonary fibrosis patients: stable versus acute exacerbation," Monaldi Archives for Chest Disease, vol. 90, no. 2, 2020.

[124] C. Machahua, S. A. Guler, M. P. Horn et al., "Serum calprotectin as new biomarker for disease severity in idiopathic pulmonary fibrosis: a cross-sectional study in two independent cohorts," BMJ Open Respiratory Research, vol. 8, no. 1, p. e000827, 2021.
[125] M. Boruk, C. Railwah, A. Lora et al., "Elevated S100A9 expression in chronic rhinosinusitis coincides with elevated MMP production and proliferation in vitro," Scientific Reports, vol. 10, no. 1, p. 16350, 2020.

[126] T. Huan, T. Esko, M. J. Peters et al., "A meta-analysis of gene expression signatures of blood pressure and hypertension," PLoS Genetics, vol. 11, no. 3, pp. e1005035-e1005035, 2015.

[127] P. A. Singleton, T. Mirzapoiazova, Y. Guo et al., "Highmolecular-weight hyaluronan is a novel inhibitor of pulmonary vascular leakiness," American Journal of Physiology. Lung Cellular and Molecular Physiology, vol. 299, no. 5, pp. L639-L651, 2010.

[128] K. Katono, Y. Sato, S.-X. Jiang et al., "Clinicopathological significance of S100A10 expression in lung adenocarcinomas," Asian Pacific Journal of Cancer Prevention, vol. 17, no. 1, pp. 289-294, 2016.

[129] K. Sato, Y. Saiki, K. Arai et al., "S100A10 upregulation associates with poor prognosis in lung squamous cell carcinoma," Biochemical and Biophysical Research Communications, vol. 505, no. 2, pp. 466-470, 2018.

[130] G. Pampalakis, E. Zingkou, K. G. Sidiropoulos et al., "Biochemical pathways mediated by KLK6 protease in breast cancer," Molecular Oncology, vol. 13, no. 11, pp. 2329-2343, 2019.

[131] T. Woo, K. Okudela, H. Mitsui et al., "Up-regulation of S100A11 in lung adenocarcinoma - its potential relationship with cancer progression," PLoS One, vol. 10, no. 11, article e0142642, 2015.

[132] H. Bouzina, R. Hesselstrand, and G. Rådegran, "Plasma insulin-like growth factor binding protein 1 in pulmonary arterial hypertension," Scandinavian Cardiovascular Journal, vol. 55, pp. 35-42, 2021.

[133] C. Fan, Z. Fu, Q. Su, D. J. Angelini, J. van Eyk, and R. A. Johns, "S100A11 mediates hypoxia-induced mitogenic factor (HIMF)-induced smooth muscle cell migration, vesicular exocytosis, and nuclear activation," Molecular \& Cellular Proteomics, vol. 10, no. 3, p. M110.000901, 2011.

[134] H. Wittkowski, A. Sturrock, M. A. van Zoelen et al., "Neutrophil-derived S100A12 in acute lung injury and respiratory distress syndrome," Critical Care Medicine, vol. 35, no. 5, pp. 1369-1375, 2007.

[135] M. A. Hofmann Bowman, A. Heydemann, J. Gawdzik, R. A. Shilling, and B. Camoretti-Mercado, "Transgenic expression of human S100A12 induces structural airway abnormalities and limited lung inflammation in a mouse model of allergic inflammation," Clinical and Experimental Allergy, vol. 41, no. 6, pp. 878-889, 2011.

[136] W. Wen, W. Su, H. Tang et al., "Immune cell profiling of COVID-19 patients in the recovery stage by single- cell sequencing," Cell discovery, vol. 6, no. 1, p. 31, 2020.

[137] J. Schulte-Schrepping, N. Reusch, D. Paclik et al., "Severe COVID-19 is marked by a dysregulated myeloid cell compartment," Cell, vol. 182, no. 6, pp. 1419-1440.e23, 2020.

[138] K. Katono, Y. Sato, M. Kobayashi et al., "Clinicopathological significance of S100A14 expression in lung adenocarcinoma," Oncology research and treatment, vol. 40, no. 10, pp. 594-602, 2017.

[139] W. Zhao, T. Chen, and Y. Zhao, "Upregulated lncRNA CASC9 contributes to progression of non-small cell lung cancer through inhibition of miR-335-3p and activation S100A14 expression," Oncotargets and Therapy, vol. 13, pp. 6027-6036, 2020. 
[140] Y. C. Chen, M. C. Lin, C. C. Hsiao et al., "Increased S100A15 expression and decreased DNA methylation of its gene promoter are involved in high metastasis potential and poor outcome of lung adenocarcinoma," Oncotarget, vol. 8, no. 28, pp. 45710-45724, 2017.

[141] L. Sun, Z. Zhang, Y. Yao, W. Y. Li, and J. Gu, "Analysis of expression differences of immune genes in non-small cell lung cancer based on TCGA and ImmPort data sets and the application of a prognostic model," Annals of translational medicine, vol. 8, no. 8, pp. 550-550, 2020.

[142] K. Saito, M. Kobayashi, R. Nagashio et al., "S100A16 is a prognostic marker for lung adenocarcinomas," Asian Pacific Journal of Cancer Prevention, vol. 16, no. 16, pp. 70397044, 2015.

[143] L. Peng, L. Xu, and W. Ouyang, "Role of peripheral inflammatory markers in postoperative cognitive dysfunction (POCD): a meta-analysis," PLoS One, vol. 8, no. 11, article e79624, 2013.

[144] E. Higgins, G. Edwards, J. Tanguay, and M. Button, "93P: chemoradiotherapy with radical intent for small cell lung cancer (SCLC): a 5 year retrospective review," Journal of Thoracic Oncology, vol. 11, no. 4, p. S97, 2016.

[145] S. Mu, H. Ma, J. Shi, and D. Zhen, "The expression of S100B protein in serum of patients with brain metastases from small-cell lung cancer and its clinical significance," Oncology Letters, vol. 14, no. 6, pp. 7107-7110, 2017.

[146] B. S. Tan, M. C. Yang, S. Singh et al., "IncRNA NORAD is repressed by the YAP pathway and suppresses lung and breast cancer metastasis by sequestering S100P," Oncogene, vol. 38, no. 28, pp. 5612-5626, 2019.

[147] R. Hu, K. E. Huffman, M. Chu, Y. Zhang, J. D. Minna, and Y. Yu, "Quantitative secretomic analysis identifies extracellular protein factors that modulate the metastatic phenotype of non-small cell lung cancer," Journal of Proteome Research, vol. 15, no. 2, pp. 477-486, 2016.

[148] Z. Wang and X. Chen, "Establishment and validation of an immune-associated signature in lung adenocarcinoma," International Immunopharmacology, vol. 88, p. 106867, 2020.

[149] B. Bartling, G. Rehbein, A. Simm, R. E. Silber, and H. S. Hofmann, "Porcupine expression is associated with the expression of S100P and other cancer-related molecules in nonsmall cell lung carcinoma," International Journal of Oncology, vol. 36, no. 4, pp. 1015-1021, 2010.

[150] M. Moll, R. B. Christmann, Y. Zhang et al., "Patients with systemic sclerosis-associated pulmonary arterial hypertension express a genomic signature distinct from patients with interstitial lung disease," Journal of scleroderma and related disorders, vol. 3, no. 3, pp. 242-248, 2018.

[151] Y. Dempsie, M. Nilsen, K. White et al., "Development of pulmonary arterial hypertension in mice over-expressing S100A4/Mts1 is specific to females," Respiratory Research, vol. 12, no. 1, p. 159, 2011.

[152] X. Xu, H. Chen, X. Zhu et al., "S100A9 promotes human lung fibroblast cells activation through receptor for advanced glycation end-product-mediated extracellular-regulated kinase $1 / 2$, mitogen-activated protein-kinase and nuclear factor$\kappa \mathrm{B}$-dependent pathways," Clinical and Experimental Immunology, vol. 173, no. 3, pp. 523-535, 2013.

[153] P. Geraghty, A. J. Dabo, and J. D'Armiento, “TLR4 protein contributes to cigarette smoke-induced matrix metalloproteinase-1 (MMP-1) expression in chronic obstruc- tive pulmonary disease," The Journal of Biological Chemistry, vol. 286, no. 34, pp. 30211-30218, 2011.

[154] A. B. Robinson, J. A. Stogsdill, J. B. Lewis, T. T. Wood, and P. R. Reynolds, "RAGE and tobacco smoke: insights into modeling chronic obstructive pulmonary disease," Frontiers in Physiology, vol. 3, p. 301, 2012.

[155] T. Betsuyaku, M. Tanino, K. Nagai, Y. Nasuhara, M. Nishimura, and R. M. Senior, "Extracellular matrix metalloproteinase inducer is increased in smokers' bronchoalveolar lavage fluid," American Journal of Respiratory and Critical Care Medicine, vol. 168, no. 2, pp. 222-227, 2003.

[156] W. R. Swindell, A. Johnston, X. Xing et al., "Robust shifts in S100a9 expression with aging: a novel mechanism for chronic inflammation," Scientific Reports, vol. 3, no. 1, p. 1215, 2013.

[157] L. V. Portela, A. B. Tort, D. V. Schaf et al., "The serum S100B concentration is age dependent," Clinical Chemistry, vol. 48, no. 6, pp. 950-952, 2002.

[158] M. Wiesmann, U. Missler, D. Gottmann, and S. Gehring, "Plasma S-100b protein concentration in healthy adults is age- and sex-independent," Clinical Chemistry, vol. 44, no. 5, pp. 1056-1058, 1998.

[159] C. Ryckman, K. Vandal, P. Rouleau, M. Talbot, and P. A. Tessier, "Proinflammatory activities of S100: proteins S100A8, S100A9, and S100A8/A9 induce neutrophil chemotaxis and adhesion," Journal of Immunology, vol. 170, no. 6, pp. 3233-3242, 2003.

[160] P. Cheng, C. A. Corzo, N. Luetteke et al., "Inhibition of dendritic cell differentiation and accumulation of myeloidderived suppressor cells in cancer is regulated by S100A9 protein," The Journal of Experimental Medicine, vol. 205, no. 10, pp. 2235-2249, 2008.

[161] G. Sorci, G. Giovannini, F. Riuzzi et al., "The danger signal S100B integrates pathogen- and danger-sensing pathways to restrain inflammation," PLoS Pathogens, vol. 7, no. 3, article e1001315, 2011.

[162] J. Steiner, N. Marquardt, I. Pauls et al., "Human CD8 ${ }^{+}$T cells and NK cells express and secrete S100B upon stimulation," Brain, Behavior, and Immunity, vol. 25, no. 6, pp. 12331241, 2011.

[163] J. Goyette, W. X. Yan, E. Yamen et al., "Pleiotropic roles of S100A12 in coronary atherosclerotic plaque formation and rupture," Journal of Immunology, vol. 183, no. 1, pp. 593603, 2009.

[164] M. Schneider, S. Kostin, C. C. Strøm et al., "S100A4 is upregulated in injured myocardium and promotes growth and survival of cardiac myocytes," Cardiovascular Research, vol. 75, no. 1, pp. 40-50, 2007.

[165] E. Källberg, T. Vogl, D. Liberg et al., "S100A9 interaction with TLR4 promotes tumor growth," PLoS One, vol. 7, no. 3, article e34207, 2012.

[166] P. Björk, A. Björk, T. Vogl et al., "Identification of human S100A9 as a novel target for treatment of autoimmune disease via binding to quinoline-3-carboxamides," PLoS Biology, vol. 7, no. 4, p. e97, 2009.

[167] G. Giovannoni, V. Knappertz, J. R. Steinerman et al., “A randomized, placebo-controlled, phase 2 trial of laquinimod in primary progressive multiple sclerosis," Neurology, vol. 95, no. 8, pp. e1027-e1040, 2020.

[168] R. Pili, M. Häggman, W. M. Stadler et al., "Phase II randomized, double-blind, placebo-controlled study of tasquinimod in men with minimally symptomatic metastatic castrate- 
resistant prostate cancer," Journal of Clinical Oncology, vol. 29, no. 30, pp. 4022-4028, 2011.

[169] K. Jennbacken, K. Welén, A. Olsson et al., "Inhibition of metastasis in a castration resistant prostate cancer model by the quinoline-3-carboxamide tasquinimod (ABR-215050)," Prostate, vol. 72, no. 8, pp. 913-924, 2012.

[170] C. Sternberg, A. Armstrong, R. Pili et al., "Randomized, double-blind, placebo-controlled phase III study of tasquinimod in men with metastatic castration-resistant prostate cancer," Journal of Clinical Oncology, vol. 34, no. 22, pp. 2636-2643, 2016.

[171] B. Escudier, S. Faivre, E. van Cutsem et al., "A phase II multicentre, open-label, proof-of-concept study of tasquinimod in hepatocellular, ovarian, renal cell, and gastric cancers," Targeted Oncology, vol. 12, no. 5, pp. 655-661, 2017.

[172] G. Comi, D. Jeffery, L. Kappos et al., "Placebo-controlled trial of oral laquinimod for multiple sclerosis," The New England Journal of Medicine, vol. 366, no. 11, pp. 1000-1009, 2012.

[173] On behalf of the BRAVO Study Group, T. L. Vollmer, P. S. Sorensen et al., "A randomized placebo-controlled phase III trial of oral laquinimod for multiple sclerosis," Journal of Neurology, vol. 261, no. 4, pp. 773-783, 2014.

[174] M. Stenström, H. C. Nyhlén, M. Törngren et al., "Paquinimod reduces skin fibrosis in tight skin 1 mice, an experimental model of systemic sclerosis," Journal of Dermatological Science, vol. 83, no. 1, pp. 52-59, 2016.

[175] S. Tahvili, M. Törngren, D. Holmberg, T. Leanderson, and F. Ivars, "Paquinimod prevents development of diabetes in the non-obese diabetic (NOD) mouse," PLoS One, vol. 13, no. 5, article e0196598, 2018.

[176] A. A. Bengtsson, G. Sturfelt, C. Lood et al., "Pharmacokinetics, tolerability, and preliminary efficacy of paquinimod (ABR-215757), a new quinoline-3-carboxamide derivative: studies in lupus-prone mice and a multicenter, randomized, double-blind, placebo-controlled, repeat-dose, dose-ranging study in patients with systemic lupus erythematosus," Arthritis and Rheumatism, vol. 64, no. 5, pp. 1579-1588, 2012.

[177] "Exploratory study of changes in disease activity and biomarkers with ABR-215757 in patients with mild active systemic lupus erythematosus (SLE)," ClinicalTrials.Gov identifier: NCT00997100.

[178] T. Arumugam, V. Ramachandran, D. Sun et al., "Designing and developing S100P inhibitor 5-methyl cromolyn for pancreatic cancer therapy," Molecular Cancer Therapeutics, vol. 12, no. 5, pp. 654-662, 2013.

[179] P. Björk, E. Källberg, U. Wellmar et al., "Common interactions between S100A4 and S100A9 defined by a novel chemical probe," PLoS One, vol. 8, no. 5, article e63012, 2013.

[180] N. G. Dulyaninova, K. M. Hite, W. D. Zencheck et al., "Cysteine 81 is critical for the interaction of S100A4 and myosinIIA," Biochemistry, vol. 50, no. 33, pp. 7218-7227, 2011.

[181] T. R. Reddy, C. Li, P. M. Fischer, and L. V. Dekker, "Threedimensional pharmacophore design and biochemical screening identifies substituted 1,2,4-triazoles as inhibitors of the annexin A2-S100A10 protein interaction," ChemMedChem, vol. 7, no. 8, pp. 1435-1446, 2012.

[182] C. Yoshimura, T. Miyafusa, and K. Tsumoto, "Identification of small-molecule inhibitors of the human S100B-p53 interaction and evaluation of their activity in human melanoma cells," Bioorganic \& Medicinal Chemistry, vol. 21, no. 5, pp. 1109-1115, 2013.
[183] D. B. Zimmer, R. G. Lapidus, and D. J. Weber, "In vivo screening of S100B inhibitors for melanoma therapy," Methods in Molecular Biology, vol. 963, pp. 303-317, 2013.

[184] M. Okada, H. Tokumitsu, Y. Kubota, and R. Kobayashi, "Interaction of S100 proteins with the antiallergic drugs, olopatadine, amlexanox, and cromolyn: identification of putative drug binding sites on S100A1 protein," Biochemical and Biophysical Research Communications, vol. 292, no. 4, pp. 1023-1030, 2002.

[185] U. Sack, W. Walther, D. Scudiero et al., "S100A4-induced cell motility and metastasis is restricted by the $\mathrm{Wnt} / \beta$-catenin pathway inhibitor calcimycin in colon cancer cells," Molecular Biology of the Cell, vol. 22, no. 18, pp. 3344-3354, 2011.

[186] U. Stein, F. Arlt, J. Smith et al., "Intervening in $\beta$-catenin signaling by sulindac inhibits S100A4-dependent colon cancer metastasis," Neoplasia, vol. 13, no. 2, pp. 131-IN8, 2011.

[187] L. Liu, "Inhibition of lung surfactant secretion by KN-62, a specific inhibitor of the calcium- and calmodulin-dependent protein kinase II," Biochemistry and Molecular Biology International, vol. 45, no. 4, pp. 823-830, 1998.

[188] E. Vara, J. Arias-Díaz, C. Garcia, J. L. Balibrea, and E. Blázquez, "Glucagon-like peptide-1(7-36) amide stimulates surfactant secretion in human type II pneumocytes," American Journal of Respiratory and Critical Care Medicine, vol. 163, no. 4, pp. 840-846, 2001.

[189] M. Xiang, Z. Chen, D. Yang et al., "Niclosamide enhances the antitumor effects of radiation by inhibiting the hypoxiainducible factor- $1 \alpha /$ vascular endothelial growth factor signaling pathway in human lung cancer cells," Oncology Letters, vol. 14, no. 2, pp. 1933-1938, 2017.

[190] R. Boyapally, G. Pulivendala, S. Bale, and C. Godugu, "Niclosamide alleviates pulmonary fibrosis in vitro and in vivo by attenuation of epithelial-to-mesenchymal transition, matrix proteins \& Wnt/ $\beta$-catenin signaling: a drug repurposing study," Life Sciences, vol. 220, pp. 8-20, 2019.

[191] R. Verma, M. Brahmankar, L. Kushwah, and B. Suresh, "Evaluating the inhibitory potential of sulindac against the bleomycin-induced pulmonary fibrosis in Wistar rats," Environmental Toxicology and Pharmacology, vol. 36, no. 3, pp. 769-778, 2013.

[192] C. Cirillo, E. Capoccia, T. Iuvone et al., "S100B inhibitor pentamidine attenuates reactive gliosis and reduces neuronal loss in a mouse model of Alzheimer's disease," BioMed Research International, vol. 2015, Article ID 508342, 11 pages, 2015.

[193] L. Seguella, F. Rinaldi, C. Marianecci et al., "Pentamidine niosomes thwart $\mathrm{S} 100 \mathrm{~B}$ effects in human colon carcinoma biopsies favouring wtp53 rescue," Journal of Cellular and Molecular Medicine, vol. 24, no. 5, pp. 3053-3063, 2020.

[194] T. Mori, T. Town, J. Tan, N. Tateishi, and T. Asano, "Modulation of astrocytic activation by arundic acid (ONO-2506) mitigates detrimental effects of the apolipoprotein $\mathrm{E} 4$ isoform after permanent focal ischemia in apolipoprotein $\mathrm{E}$ knock-in mice," Journal of Cerebral Blood Flow and Metabolism, vol. 25, no. 6, pp. 748-762, 2005.

[195] J. Klingelhöfer, B. Grum-Schwensen, M. K. Beck et al., “AntiS100A4 antibody suppresses metastasis formation by blocking stroma cell invasion," Neoplasia, vol. 14, no. 12, pp. 1260-IN47, 2012.

[196] S. Dakhel, L. Padilla, J. Adan et al., "S100P antibody-mediated therapy as a new promising strategy for the treatment of pancreatic cancer," Oncogene, vol. 3, no. 3, article e92, 2014. 
[197] H. Qin, B. Lerman, I. Sakamaki et al., "Generation of a new therapeutic peptide that depletes myeloid-derived suppressor cells in tumor-bearing mice," Nature Medicine, vol. 20, no. 6, pp. 676-681, 2014.

[198] S. Bruhn, Y. Fang, F. Barrenas et al., "A generally applicable translational strategy identifies S100A4 as a candidate gene in allergy," Science Translational Medicine, vol. 6, no. 218, p. 218ra4, 2014.

[199] A. Dhar, S. Mallick, P. Ghosh et al., "Simultaneous inhibition of key growth pathways in melanoma cells and tumor regression by a designed bidentate constrained helical peptide," Biopolymers, vol. 102, no. 4, pp. 344-358, 2014.

[200] T. Kawano, M. Shimamura, H. Nakagami et al., "Therapeutic vaccine against S100A9 (S100 calcium-binding protein A9) inhibits thrombosis without increasing the risk of bleeding in ischemic stroke in mice," Hypertension, vol. 72, no. 6, pp. 1355-1364, 2018.

[201] P. Most, S. T. Pleger, M. Völkers et al., "Cardiac adenoviral S100A1 gene delivery rescues failing myocardium," The Journal of Clinical Investigation, vol. 114, no. 11, pp. 1550-1563, 2004.

[202] S. T. Pleger, C. Shan, J. Ksienzyk et al., "Cardiac AAV9S100A1 gene therapy rescues post-ischemic heart failure in a preclinical large animal model," Science Translational Medicine, vol. 3, no. 92, p. 92ra64, 2011.

[203] T. Ravasi, K. Hsu, J. Goyette et al., "Probing the S100 protein family through genomic and functional analysis," Genomics, vol. 84, no. 1, pp. 10-22, 2004.

[204] J. Edgeworth, M. Gorman, R. Bennett, P. Freemont, and N. Hogg, "Identification of p8,14 as a highly abundant heterodimeric calcium binding protein complex of myeloid cells," The Journal of Biological Chemistry, vol. 266, no. 12, pp. 7706-7713, 1991.

[205] M. R. Tardif, J. A. Chapeton-Montes, A. Posvandzic, N. Pagé, C. Gilbert, and P. A. Tessier, "Secretion of S100A8, S100A9, and S100A12 by neutrophils involves reactive oxygen species and potassium efflux," Journal of Immunology Research, vol. 2015, Article ID 296149, 16 pages, 2015.

[206] V. Schenten, S. Bréchard, S. Plançon, C. Melchior, J. P. Frippiat, and E. J. Tschirhart, "IPLA ${ }_{2}$, a novel determinant in $\mathrm{Ca}^{2+}$ - and phosphorylation-dependent S100A8/A9 regulated NOX2 activity," Biochimica et Biophysica Acta, vol. 1803, no. 7, pp. 840-847, 2010.

[207] V. Schenten, C. Melchior, N. Steinckwich, E. J. Tschirhart, and S. Brechard, "Sphingosine kinases regulate NOX2 activity via p38 MAPK-dependent translocation of S100A8/A9," Journal of Leukocyte Biology, vol. 89, no. 4, pp. 587-596, 2011.

[208] R. A. Newton and N. Hogg, "The human S100 protein MRP-14 is a novel activator of the beta 2 integrin Mac-1 on neutrophils," Journal of Immunology, vol. 160, no. 3, pp. 1427-1435, 1998.

[209] S. C. Fagerholm, C. Guenther, M. Llort Asens, T. Savinko, and L. M. Uotila, "Beta2-Integrins and interacting proteins in leukocyte trafficking, immune suppression, and immunodeficiency disease," Frontiers in Immunology, vol. 10, p. 254, 2019.

[210] A. Silvin, N. Chapuis, G. Dunsmore et al., "Elevated calprotectin and abnormal myeloid cell subsets discriminate severe from mild COVID-19," Cell, vol. 182, no. 6, pp. 14011418.e18, 2020.

[211] M. S. Abers, O. M. Delmonte, E. E. Ricotta et al., "An immune-based biomarker signature is associated with mortality in COVID-19 patients," JCI Insight, vol. 6, no. 1, 2021.
[212] L. G. de Guadiana Romualdo, M. D. R. Mulero, M. H. Olivo et al., "Circulating levels of GDF-15 and calprotectin for prediction of in-hospital mortality in COVID-19 patients: a case series," The Journal of Infection, vol. 82, no. 2, pp. e40-e42, 2021.

[213] E. Petito, E. Falcinelli, U. Paliani et al., "Association of neutrophil activation, more than platelet activation, with thrombotic complications in coronavirus disease 2019," The Journal of Infectious Diseases, vol. 223, no. 6, pp. 933-944, 2021.

[214] H. Shi, Y. Zuo, S. Yalavarthi et al., "Neutrophil calprotectin identifies severe pulmonary disease in COVID-19," Journal of Leukocyte Biology, vol. 109, no. 1, pp. 67-72, 2021.

[215] M. Effenberger, F. Grabherr, L. Mayr et al., "Faecal calprotectin indicates intestinal inflammation in COVID-19," Gut, vol. 69, no. 8, pp. 1543-1544, 2020.

[216] V. Ojetti, A. Saviano, M. Covino et al., "COVID-19 and intestinal inflammation: role of fecal calprotectin," Digestive and Liver Disease, vol. 52, no. 11, pp. 1231-1233, 2020.

[217] A. Aceti, L. M. Margarucci, E. Scaramucci et al., "Serum S100B protein as a marker of severity in COVID-19 patients," Scientific Reports, vol. 10, no. 1, p. 18665, 2020.

[218] Q. Guo, Y. Zhao, J. Li et al., "Induction of alarmin S100A8/A9 mediates activation of aberrant neutrophils in the pathogenesis of COVID-19," Cell Host \& Microbe, vol. 29, no. 2, pp. 222-235.e4, 2021.

[219] Y. Liu, J. Cui, Y. L. Tang, L. Huang, C. Y. Zhou, and J. X. Xu, "Prognostic roles of mRNA expression of S100 in non-smallcell lung cancer," BioMed Research International, vol. 2018, Article ID 9815806, 11 pages, 2018.

[220] Z. Qi, T. Li, F. Kong et al., "The characteristics and function of S100A7 induction in squamous cell carcinoma: heterogeneity, promotion of cell proliferation and suppression of differentiation," PLoS One, vol. 10, no. 6, article e0128887, 2015.

[221] M. W. Nasser, N. A. Wani, D. K. Ahirwar et al., "RAGE mediates S100A7-induced breast cancer growth and metastasis by modulating the tumor microenvironment," Cancer Research, vol. 75, no. 6, pp. 974-985, 2015.

[222] L. Núñez-Naveira, L. A. Mariñas-Pardo, and C. MonteroMartínez, "Mass spectrometry analysis of the exhaled breath condensate and proposal of dermcidin and S100A9 as possible markers for lung cancer prognosis," Lung, vol. 197, no. 4, pp. 523-531, 2019.

[223] K. Okudela, A. Katayama, T. Woo et al., "Proteome analysis for downstream targets of oncogenic KRAS-the potential participation of CLIC4 in carcinogenesis in the lung," PLoS One, vol. 9, no. 2, article e87193, 2014.

[224] H. Bouzina, R. Hesselstrand, and G. Rådegran, "Plasma insulin-like growth factor binding protein 1 in pulmonary arterial hypertension," Scandinavian Cardiovascular Journal, vol. 55, no. 1, pp. 35-42, 2021.

[225] M. A. Kovach, K. A. Stringer, R. Bunting et al., "Microarray analysis identifies IL-1 receptor type 2 as a novel candidate biomarker in patients with acute respiratory distress syndrome," Respiratory Research, vol. 16, no. 1, p. 29, 2015.

[226] D. Massi, M. Landriscina, A. Piscazzi et al., "S100A13 is a new angiogenic marker in human melanoma," Modern Pathology, vol. 23, no. 6, pp. 804-813, 2010.

[227] T. Sugino, N. Ichikawa-Tomikawa, M. Tanaka et al., "Identification of S100A14 as a metastasis-promoting molecule in a murine organotropic metastasis model," Clinical \& Experimental Metastasis, vol. 36, no. 4, pp. 411-422, 2019. 
[228] F. Ding, D. Wang, X. K. Li et al., "Overexpression of S100A14 contributes to malignant progression and predicts poor prognosis of lung adenocarcinoma," Thorac Cancer, vol. 9, no. 7, pp. 827-835, 2018.

[229] M. Ichinose, H. Sugiura, H. Nagase et al., "Japanese guidelines for adult asthma 2017," Allergology International, vol. 66, no. 2, pp. 163-189, 2017.

[230] V. N. Malashkevich, N. G. Dulyaninova, U. A. Ramagopal et al., "Phenothiazines inhibit S100A4 function by inducing protein oligomerization," Proceedings of the National Academy of Sciences of the United States of America, vol. 107, no. 19, pp. 8605-8610, 2010.

[231] L. C. Pettigrew, S. E. Kasner, G. W. Albers et al., "Safety and tolerability of arundic acid in acute ischemic stroke," Journal of the Neurological Sciences, vol. 251, no. 1-2, pp. 50-56, 2006.

[232] U. Sack, W. Walther, D. Scudiero et al., "Novel effect of antihelminthic Niclosamide on S100A4-mediated metastatic progression in colon cancer," Journal of the National Cancer Institute, vol. 103, no. 13, pp. 1018-1036, 2011. 